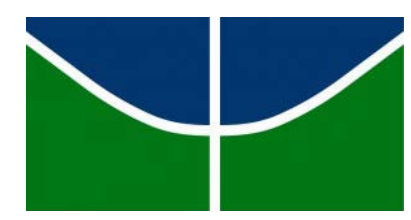

Universidade de Brasília

Instituto de Artes

Licenciatura em Teatro

\title{
O EXERCÍCIO CÊNICO EM SALA DE AULA SOB A PERSPECTIVA DA EDUCAÇÃO INCLUSIVA: UMA EXPERIÊNCIA NA ESCOLA ESTADUAL ANTÔNIO EPAMINONDAS EM CUIABÁ-MT
}

Eduardo de Freitas Butakka

Barra do Bugres/MT 
EDUARDO DE FREITAS BUTAKKA

\section{O EXERCÍCIO CÊNICO EM SALA DE AULA SOB A PERSPECTIVA DA EDUCAÇÃO INCLUSIVA: UMA EXPERIÊNCIA NA ESCOLA ESTADUAL ANTÔNIO EPAMINONDAS EM CUIABÁ-MT}

Trabalho de conclusão do curso de Licenciatura em Teatro do Instituto de Artes da Universidade de Brasília, sob orientação da Prof. ${ }^{a}$ Ma. Cilene Rodrigues Carneiro Freitas. 
EDUARDO DE FREITAS BUTAKKA

O EXERCÍCIO CÊNICO EM SALA de AUla SOB A PERSPECTIVA DA EDUCAÇÃO INCLUSIVA: UMA EXPERIÊNCIA NA ESCOLA ESTADUAL ANTÔNIO EPAMINONDAS EM CUIABÁ-MT

Trabalho de conclusão de curso aprovado, apresentado a UnB - Universidade de Brasília, no Instituto de Artes, Departamento de Artes Cênicas- CEN como requisito para obtenção do título de Licenciatura em Teatro com nota final igual a 55.95 sob a orientação do (a) professor (a) Mestre Cilene Rodrigues Carneiro Freitas.

Barra do Bugres-MT, 20 de fevereiro de 2018.

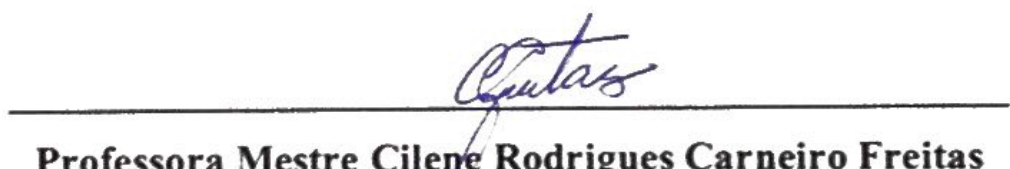

Professora Mestre Cilene Rodrigues Carneiro Freitas

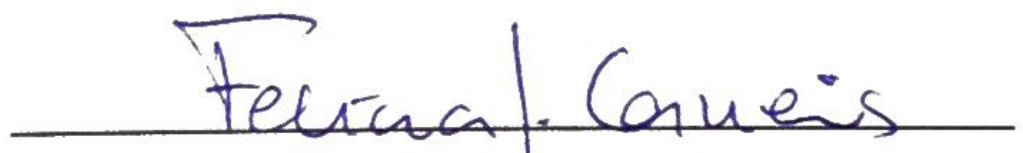

Professora Doutora Feligia Johansson Carneiro

fuare Seivor Pacheco

Professora Doutora Sulian Vieira Pacheco 
Dedico este trabalho aos meus pais, José e Vera, por sempre acreditarem em mim, ainda que desacreditando minhas escolhas.

Ao Lucas, meu companheiro, por compartilhar minhas alegrias e tristezas.

Ao meu irmão, Marcelo, e às minhas irmãs Maíra e Elayne, por serem meus primeiros amigos desde sempre.

Aos meus amigos do peito, Ana, Mayra, Karol, Monique, Jean, Thyago, Lorena, Heidy e Driélle.

E ao Felipe 'Dumont' Duarte, por instigar em mim a paixão pelo teatro. Ainda que partindo cedo demais. 


\section{AGRADECIMENTOS}

Agradeço a toda equipe de docentes do curso de Licenciatura em Teatro da Universidade de Brasília, em especial:

À Prof. ${ }^{a}$ Dr. ${ }^{a}$ SulianVieira Pacheco, por sempre estar diposta a me apoiar diante às adversidades.

À Prof. ${ }^{a}$ Ma. Débora Silva de Azevedo, por suscitar em mim o uso pleno do meu potencial.

À Prof. ${ }^{a}$ Erenil Oliveira Magalhães, tutora presencial do curso, que nunca mediu esforços para me dar todo o suporte necessário.

À minha orientadora, Prof. ${ }^{a}$ Ma. Cilene Rodrigues Carneiro Freitas, que se prontificou em me ajudar nessa importante missão acadêmica, proporcionando-me um apoio integral.

E a todos os meus colegas de curso, do polo de Barra do Bugres, por não me deixarem desistir e por manterem sempre viva a chama da Arte. 
Se eu puder evitar que um coração se parta.

Não viverei em vão.

Se eu puder suavizar a aflição de uma vida.

Aplacar uma dor,

Ou ajudar um frágil passarinho.

A retornar ao ninho, Não viverei em vão.

(Emily Dickinson) 


\section{RESUMO}

Este trabalho parte as observações feitas durante as aulas de estágio do curso de Licenciatura em Teatro, em particular a respeito das dificuldades de se trabalhar com alunos com necessidades educacionais especiais no ensino regular. Como objetivo geral, visa compreender o ensino do Teatro na educação formal sob a perspectiva da inclusão. Seus objetivos específicos incluem: apresentar as concepções de Educação Inclusiva; identificar a contribuição do Teatro na inclusão de alunos na educação formal e relatar os jogos teatrais e dramáticos utilizados nas aulas, bem como as apreensões dos estudantes, dialogando com o referencial teórico pesquisado. Trata-se de uma pesquisa, com abordagem qualitativa, realizada em uma turma de ensino médio da rede pública na cidade de Cuiabá, estado de Mato Grosso. Apresenta como resultado as observações sobre o despreparo dos professores ao trabalharem com educandos com dificuldades acentuadas de aprendizagem. Aborda, ainda, a importância do ensino do Teatro como ferramenta de percepção das necessidades educacionais especiais dos alunos e de potencialização de suas habilidades ao estimular a auto-expressão, a autoestima, a sensibilidade estética, o respeito ao direito à diversidade e o exercício pleno da cidadania.

Palavras-chave: inclusão - jogos teatrais e dramáticos - Necessidades educacionais especiais 


\begin{abstract}
This work is based on the observations made during the internship classes of the Degree in Theater, in particular about the difficulties of working with students with special educational needs in regular education. As a general objective, it aims to understand Theater teaching in formal education from the perspective of inclusion. Its specific objectives include: presenting the conceptions of Inclusive Education; to identify the contribution of the Theater in the inclusion of students in formal education and to report the theater games and drama games used in the classes, as well as the students' apprehensions, in dialogue with the researched theoretical framework. This is a qualitative research carried out in a high school classroom of the public school system in the city of Cuiabá, state of Mato Grosso. It presents as a result the observations about the teachers' unpreparedness when working with students with marked learning disabilities. It also addresses the importance of Theater teaching as a tool for the perception of students' special educational needs and for enhancing their abilities by stimulating self-expression, self-esteem, aesthetic sensibility, respect for the right to diversity and full exercise of citizenship.
\end{abstract}

Keywords: inclusion - theater games and drama games - Special Educational Needs 


\section{LISTA DE IMAGENS}

Imagem 1 - As seis expressões faciais básicas

Imagem 2 - Jogo "Janela indiscreta". Escola Estadual Antônio Epaminondas. Cuiabá-MT, 2017. Foto Eduardo Butakka .39

Imagem 3 - Drama em sala de aula. Escola Estadual Antônio Epaminondas. Cuiabá-MT, 2017. Foto Eduardo Butakka ..... .40 
SUMÁRIO

INTRODUÇÃO.

CAPÍTULO 1 - A EDUCAÇÃO INCLUSIVA NO BRASIL

1.1 - Alunos com Necessidades educacionais especiais (NEEs): integrar ou incluir? .20

CAPÍTULO 2 - A EXPERIÊNCIA DE ESTÁGIO E O ENSINO DO TEATRO NAS ESCOLAS: UMA PROPOSTA INCLUSIVA?.

2.1 - A noção de jogo e Drama no Teatro

2.2 - Memórias de um Professor de Teatro na educação formal com alunos com necessidades educacionais especiais

CONSIDERAÇÕES FINAIS

REFERÊNCIAS BIBLIOGRÁFICAS.

ANEXOS.

I - Diários de bordo mencionados durante o trabalho .53

II - Alguns modelos de planos de aula realizados surante o estágio 


\section{INTRODUÇÃO}

O trabalho a seguir propõe o diálogo a respeito do ensino de Teatro na educação formal com Alunos com necessidades educacionais especiais, ou seja, "crianças e jovens cujas necessidades decorram de sua elevada capacidade ou de suas dificuldades para aprender. Está associada, portanto, a dificuldades de aprendizagem, não necessariamente vinculada a deficiência(s)" (BRASIL, 2006). Com foco na realização de jogos teatrais e dramáticos, a pesquisa relata os desafios de se ministrar aulas de Teatro sob os preceitos da Educação Inclusiva. Aqui, a inclusão é entendida como movimento educacional, social e político que tem por objetivo defender os direitos de todo indivíduo de participar da sociedade sendo respeitado por sua diferença (FREIRE, 2008).

Este trabalho foi elaborado a partir da minha experiência no estágio do curso de Licenciatura em Teatro. A angústia gerada pelo pouco conhecimento que tinha sobre Educação Inclusiva, em especial acerca de alunos com necessidades educacionais especiais, foi crucial para que eu refletisse sobre a importância de me preparar melhor para as aulas em situações análogas. Os jogos utilizados foram adequados a todos os alunos? As minhas tentativas de adaptação dos exercícios em sala de aula se integraram a uma perspectiva de Educação Inclusiva? Qual a importância do ensino do Teatro para inclusão? Essas foram algumas indagações que me direcionaramna formulação do meu problema de pesquisa: Como

\section{trazer o exercício cênico em sala de aula sob a perspectiva da Educação Inclusiva?}

O fato narrado em questão é que não fui preparado para trabalhar com alunos com necessidades educacionais especiais (NEEs). Desde meu plano de aula, não antecipei essa possibilidade. Na prática, senti a necessidade pungente de adaptar minhas aulas a partir de uma perspectiva inclusiva. Minha primeira experiência com a inclusão de alunos com dificuldades acentuadas de aprendizagempode ser resumida como uma sucessão de episódios que variavam entre "constrangedores" a "engrandecedores". Desde, por exemplo, pedir para uma aluna com disfunção na fala "dizer seu nome", a vê-larealizando magistralmente os exercícios propostos, contrariando meu preconceito.

Esta pesquisa se faz necessária na medida em que a inclusão precisa extrapolar a teoria e se efetivar na prática das aulas de Teatro. Assumem-se aqui as dificuldades de se reconhecer alunos com necessidades educacionais especiais, uma vez que nem sempre 
dispõem de laudos periciais e os riscos de se generalizar os diagnósticos a todos os alunos "diferentes", que fujam da "normalização". Além disso, este trabalho dialoga sobre o papel da comunidade escolar na inclusão educacional e a importância dos professores de Teatro flexibilizar em seus currículos para atender toda a turma, respeitando o direito às diferenças.

Esta pesquisa é interessante também no que tange a adequação de jogos teatrais e dramáticos para que todos os alunos possam realizá-los, abstraindo-se o máximo de suas capacidades. Os jogos no Teatro são terreno fértil para ludicidade e transformação da realidade, "tendo como finalidade o crescimento pessoal e o desenvolvimento cultural dos jogadores” (JAPIASSU, 2001). Afinal, antes de se construir um futuro melhor é necessário imaginá-lo e se sentir parte dele. Assim sendo, reforça-se as obrigações do professor de Teatro do ensino regularem garantir que a linguagem poética inclua todos os alunos, independentemente de cor, classe social, orientação sexual, religião, deficiência, entre outras variáveis. O professor precisa possuir a expertise de saber reconhecer a diversidade entre os alunos e incentivar suas capacidades, com base em aulas que despertem o interesse e estimulem a aprendizagem sem segregá-los.

A partir da atenção à diversidade da comunidade escolar, admite-se que o educando não é a origem das dificuldades educacionais. Estasresidem em diversos fatores: na formação acadêmica, na escola, na família, no próprio professor e até mesmo nas políticas públicas que precisam ser reavaliadas sob a perspectiva da inclusão, para quegarantam as condições necessárias a todos de exercerem sua cidadania. É irrelevante pensar em transformação social sem se reconhecer a diversidade e sem que se criem condições de equidade em sala de aula. A escola tem o dever de educar alunos com capacidade de desenvolver atividades complexas e de se integrarem em sociedade dotados de valores universais como tolerância e respeito às diferenças (FREITE, 2008).

Sendo assim, o objetivo geral é compreender o ensino de Teatro na educação formal sob a perspectiva da inclusão. Como recorte, tratarei da inclusão de alunos com necessidades educacionais especiais no ensino regular. Os objetivos específicos desta pesquisa incluem: apresentar as concepções de Educação Inclusiva; identificar a contribuição do Teatro na inclusão de alunos naeducação formal e relatar os jogos teatrais utilizados durante o estágio em Teatro e as apreensões dos alunos, dialogando com o referencial teórico pesquisado. 
A pesquisa, com abordagem qualitativa, teve como ponto de partida as aulas que ministrei durante o estágio em Licenciatura em Teatro na Escola Estadual Antônio Epaminondas, em Cuiabá, Mato Grosso. A instituição, quese configura com a pedagogia de ensino em tempo integral e por isso seu corpo discente passa o dia todo nela, desenvolveu o projeto Balaio das Artes, no qual os alunos puderam escolher aulas de Teatro como linguagem artíticaeletiva, ou seja, aulas complementares, além das exigidas na matriz curricular. Vale ressaltar que essa escolha foi delimitada pelas opçõesofertadas aos alunos, as quais eles eram obrigados a se submeterem a pelo menos uma, e cursadas durante o horário comum de aula. As opções oferecidas dividiram-se em: Encena-me (Teatro), Inspire-me (Artes plásticas), Encanta-me (Música e instrumentos), Movimenta-me (Dança), Envolvame (Escultura regional).

Ameta do "Balaio das Artes", segundo a coordenação da escola, é promover a interdisciplinaridade entre as diversas áreas de conhecimento, em especial unir Linguagens e Ciências da Natureza, promovendo o diálogo com o cotidiano dos alunos.

Em sala de aula, havia cerca de quinze alunos que escolheram a disciplina eletiva de Teatro. A turma era formada por alunos do $1^{\circ}$ ao $3^{\circ}$ ano do Ensino Médio, com idades que variavam de 13 a 25 anos, sendo a maioria entre 15 a 17 anos de idade. Para esta pesquisa, foram atribuídos nomes fictícios. Dentre os alunos, três apresentavam dificuldades acentuadas de aprendizagem, sendo que duas, Carol e Amanda, ofereciam condutas típicas ${ }^{1}$, que ocasionavam atrasos no desenvolvimento; e uma, Beatriz, possuía disfunção na fala. Amanda, 25 anos; Carol, 22 anos; e Beatriz com 18 anos.

Percebi durante as aulas, que essas três alunas permaneciam o tempo todo juntasetinham dificuldades em aprender o mais simples dos exercícios. É claro que a aluna com disfunção na fala foi mais fácil identificar. Ela podia ouvir, mas não podia falar. No começo, até achei que se tratava de uma aluna surda, mas não era o caso. No entanto as outras duas, Amanda e Carol, eu não soube ao certo quais eram suas necessidades educacionais especiais.

\footnotetext{
${ }^{1} \mathrm{O}$ termo "condutas típicas" foi proposto na tentativa de se evitar outros rótulos, anteriormente utilizados, que carregavam, em seu significado, uma carga de julgamento e de desqualificação da pessoa a quem eles eram atribuídos. Pode-se citar, dentre estes: transtornos de conduta, distúrbios de comportamento, comportamentos disruptivos, desajuste social, distúrbios emocionais, etc. (BRASIL, 2002, p. 9)
} 
Questionei a professora de Português, que também integrava a eletiva de Teatro, sobre as alunas e esta disse que elas "nitidamente possuíam algum tipo de transtorno de déficit de atenção, mas que não possuíam laudo oficial". A professora me informou ainda que a mais velha delas, a Amanda, já havia repetido o $1^{\circ}$ ano duas vezes e que, dessa vez, provavelmente "teria que passá-la". Questionei ao coordenador pedagógico da escola a respeito do diagnóstico das alunas e este disse que a família não havia apresentado nenhum laudo médico, mas que ele poderia solicitar "caso eu precisasse".

Mesmo não sendo a intenção desta pesquisa copiar os mesmos modelos clínicos que rotulam, classificam e encaminham os alunos para os atendimentos médicos, é importante frisar que a falta de diagnóstico fez com que a insegurança em não saber lidar com essasalunas aumentasse. Ao mesmo tempo, o que sugeria de início que iria limitar as aulas, acabou me retirando da zona de conforto e me obrigandoa adequar meu plano de aula, de modo a não excluir essas alunas em relação a seus colegas. Logo, o que parecia ser uma adversidade intransponívelmostrou-se potencialmente enriquecedor.

Na busca por respostas, apresento uma pesquisa bibliográfica sobre a evolução do conceito de "Educação inclusiva”. No Brasil, as discussões sobre o assunto só se iniciaram a partir da década de 80 e só foram homologadas na Constituição Brasileira de 1988. Entretanto, foi após a Declaração de Salamanca, na década de 90, que o assunto entrou em pauta e as mudanças começaram a ser efetivadas.

A monografia está estruturada em dois capítulos: no primeiro, intitulado “A Educação Inclusiva”, explano sobre os conceitos e faço um apanhado sobre as leis que garantem no Brasil sua obrigação; no segundo capítulo, “A Experiência de Estágio e o Ensino do Teatro nas Escolas: Uma Proposta Inclusiva”, relato minha experiência como professor de Teatro que pela primeira vez trabalha com alunos com necessidades educacionais especiais. Convido a todos a conhecerem minhas impressões, os exercícios e jogos propostos e iniciar o diálogo a respeito do ensino do Teatro na educação formal e seu papelpara uma sociedade inclusiva, que precisa, cada vez mais, valorizar a diferença e a diversidade, promovendo a verdadeira transformação social livre de preconceito e discriminação. 


\title{
CAPÍTULO 1 - A EDUCAÇÃO INCLUSIVA NO BRASIL
}

A inclusão pegou as escolas de calças curtas — isso é irrefutável. (MANTOAN, 2003)

Quando se fala em Educação Inclusiva, subentende-se a pluralidade de alunos participando e compartilhando do mesmo ambiente de ensino. Preza-se nesse conceito pela diversidade e o respeito às diferenças. Desse modo, cada aluno deve ser estimulado a partir de sua potencialidade, independentemente de suas características individuais ou sociais.

\begin{abstract}
A inclusão é um movimento educacional, mas também social e político que vem defender o direito de todos os indivíduos participarem, de uma forma consciente e responsável, na sociedade de que fazem parte, e de serem aceitos e respeitados naquilo que os diferencia dos outros. No contexto educacional, vem, também, defender o direito de todos os alunos desenvolverem e concretizarem as suas potencialidades, bem como de apropriarem as competências que lhes permitam exercer o seu direito de cidadania, através de uma educação de qualidade, que foi talhada tendo em conta as suas necessidades, interesses e características. (FREIRE, 2008, p. 5)
\end{abstract}

Portanto, a Educação Inclusiva advoga contra toda e qualquer discriminação, seja ela referente à cor, gênero, classe social, cultura, religião, orientação sexual, entre outras questões. Embora essa pesquisa proponha o recorte temático ao tratar com mais ênfase das questões dos alunos com necessidades educacionais especiais nas aulas de Teatro do ensino regular, é importante destacar que o conceito de Educação Inclusiva defendido é mais abrangente. Alguns autores, no entanto,consideram a Educação Inclusiva como sendo única e exclusivamente a respeito da inserção de alunos com necessidades educacionais especiais ou distúrbios educacionais no ensino regular (MRECH, 2001).

Esse conceito mais delimitado também aparece em Aurora Ferreira (2011), que classifica a proposta da Educação Inclusiva como sendo "incluir alunos portadores de necessidades especiais nas salas do ensino regular" (p.42). 
Ressalto, no entanto, que o conceito defendido aqui é mais abrangente, tal quais as autoras Glat e Fernandes (2005) sintetizam a partir das Diretrizes Curriculares Nacionais para Educação Especial (BRASIL, 1998):

[...] implica em uma nova postura da escola regular que deve propor no projeto político-pedagógico, no currículo, na metodologia, na avaliação e nas estratégias de ensino, ações que favoreçam a inclusão social e práticas educativas diferenciadas que atendam a todos os alunos. (GLAT et FERNANDES, 2005, p. 4)

Ao se avaliar o ensino do Teatro em um ambiente formal de ensino com olhar inclusivo, faz-se necessário conhecer, antes de tudo, a legislação que rege nosso país no que tange o direito da criança e do adolescente, em particular daqueles com deficiência ou necessidades educacionais especiais e a Lei de Diretrizes e Bases da Educação Nacional (BRASIL, 1996).

O primeiro passo foi pesquisar, de um modo geral, as leis existentes que podem nortear o direito do aluno. A partir dessa pesquisa, destaca-se o que se pode considerar como marco legislativo para a Educação Inclusiva no Brasil.

A Constituição Brasileira de 1988 é a primeira delas a garantir o direito igual a todos sem discriminação. Seu Artigo 205 é enfático ao garantir o direito de "todos" à educação, sendo esta um dever do Estado e da família. O artigo discorre ainda sobre a garantia do pleno desenvolvimento da pessoa. Quando pensamos em Educação Inclusiva de modo geral, poderíamos nos dar por satisfeitos com apenas esse artigo que, apesar de abrangente, é claro ao incluir todos os cidadãos como detentores do direito à educação e ao desenvolvimento humano (BRASIL, 1988).

No entanto, é o Artigo 208 em seu parágrafo terceiro que versa sobre o "atendimento educacional especializado aos portadores de deficiência, preferencialmente na rede regular de ensino" (BRASIL, 1988, s.p.). Nesse ponto é importante diferenciar "Educação Inclusiva", conceito no qual esse trabalho se ancora, de "Educação Especial". Enquanto a primeira tem como objetivo a inclusão de pessoas no ensino regular em caráter de igualdade de condições, sempre prezando pela equidade, sem distinguir currículos; a segunda modalidade se refere a um processo educacional que visa a implantação de um projeto pedagógico para atender aos 
alunos com necessidades educacionais especiais, desenvolvendo suas potencialidades em todas as fases da educação básica.

A Educação Especial vem enfrentando duras críticas de estudiosos do assunto por defenderem que esse método categoriza alunos com necessidades educacionais especiais, partindo do ponto de suas deficiências e não de suas habilidades. Essa metodologia, segundo Dolores Affonso (2014), "os coloca numa categoria à parte, como se pertencessem a uma espécie distinta. Quando separamos as crianças para uma "Educação exclusiva”, estamos instituindo a exclusão" (s.p.). Portanto, não há o que se falar em excluir alunos com deficiência do convívio com outros alunos.

Muito embora as recomendações do Ministério da Educação para a Educação Inclusiva considerem o conceito de Educação Especial "segundo uma perspectiva mais ampla, que ultrapassa a concepção de atendimentos especializados", o mesmo reconhece que este estigma "vinha sendo sua marca nos últimos tempos". Não existem alunos sem deficiência na educação especial. Já na educação inclusiva todos os alunos com e sem deficiência tem a oportunidade de conviverem e aprenderem juntos (BRASIL, 2006, p. 40; MANTOAN, 2003).

É interessante considerar a mudança nas atitudes e o engajamento daqueles que militam por seus direitos. A legislação, a partir da Constituição Federal de 1988, passou a inserir cada vez mais em sua pauta assuntos relacionados à inclusão das pessoas na sociedade, livrando-as de qualquer tipo de discriminação (BRASIL, 1988).

Todavia, quando falamos de Educação Inclusiva, não podemos levar em conta apenas as leis que garantem o estado de direito. Desse modo, a metodologia do professor precisa ser repensada de forma a incluir todos os alunos nos assuntos que são trabalhados em sala de aula. Essa preocupação se estende à escola, que deve garantir questões básicas, como, por exemplo, acessibilidade estrutural. Afinal, o prédio de uma escola que não possui infraestrutura adequada para permitir o acesso do aluno cadeirante é excludente desde sua origem.

Diante disso, a escola precisa fomentar a discussão em torno da Educação Inclusiva junto à comunidade escolar (professores, gestores, técnicos, pais, alunos entre outros). 
Convidando a todos, para que, coletivamente, elaborem um projeto político pedagógico inclusivo, que anteveja a questão dos alunos com necessidades educacionais especiais.

Outra questão de grande relevância é a capacitação de professores para a Educação Inclusiva, desde as licenciaturas que acabam privilegiando currículos sem aplicação prática até os cursos de formação continuada. O coordenador e gestor pedagógico devem fortalecer a formação continuada de seu corpo docente sob a orientação inclusiva, buscando sempre que possível estimular projetos e cursos com esta temática. O professor precisa flexibilizar e adaptar seus métodos, estratégias e critérios de modo a atender todos os alunos no processo de ensino-aprendizagem. “A educação inclusiva pressupõe escolas abertas a todos, onde todos aprendem juntos, quaisquer que sejam as suas dificuldades”. Portanto, não basta que escola receba todos os alunos (integração), ela precisa ter a inclusão no cerne do plano político pedagógico (PPP). É este plano que vai nortear todas as ações da escola e garantir educação de qualidade a todos os alunos, além da vontade de cada agente educacional em realmente aplicar os preceitos da inclusão em sua rotina (SANCHES, 2005, p. 132).

São muitos os desafios enfrentados ainda pela Educação Inclusiva. Mudanças pedagógicas e estruturais são necessárias nas escolas a fim de garantir a todos umaeducação de qualidade. A família deve buscar conhecer e participar do projeto escolar efetivamente. O diretor deve estar aberto ao diálogo e propor que o tema paute as discussões da comunidade escolar, além de criar uma rede de apoio que envolva a família e outros profissionais especializados (fonoaudiólogos, psicólogos, fisioterapeutas, médicos etc.) (MANTOAN, 2003).

Outro marco legislativo vital para a questão da Educação Inclusiva foi a Lei n 8.069, de 13 de julho de 1990, que dispõe sobre o Estatuto da Criança e do Adolescente. Esse Estatuto corrobora com uma ótica focada na infância e adolescência sobre as questões já inauguradas pelas leis supramencionadas (BRASIL, 1990).

Embora a Constituição Brasileira já se referisse à oferta de educação especial a alunos com necessidades especiais "preferencialmente na rede regular de ensino", no Brasil, esse pensamento só começaria a ser difundido na década de 90, após a Declaração de Salamanca. Este documento foi criado durante a Conferência Mundial sobre Educação Especial, que ocorreu entre os dias 7 a 10 de junho de 1994 na cidade de Salamanca, na 
Espanha. O evento aconteceu durante um período em que líderes mundiais das Nações Unidas buscavam tornar realidade a universalização escolar. O documento, então, foi criado com o objetivo de orientar os países acerca da urgência de políticas públicas e escolares que atendam todos os alunos, sem distinções pessoais, sociais, culturais ou econômicas. A Declaração de Salamanca é considerada um marco na Educação Inclusiva e destaca a importância da inclusão educacional de alunos com necessidades educacionais especiais (BRASIL, 1998, s.p. ; SANTOS et TELES, 2012).

[...] as crianças e jovens com necessidades educativas especiais devem ter acesso às escolas regulares, que a elas se devem adequar através duma pedagogia centrada na criança, capaz de ir ao encontro destas necessidades [...] as escolas regulares, seguindo esta orientação inclusiva, constituem os meios mais capazes para combater as atitudes discriminatórias, criando comunidades abertas e solidárias, construindo uma sociedade inclusiva e atingindo a educação para todos [...] (UNESCO, 1994, p. 2)

Conhecer as leis que versam sobre inclusão é importante e saber interpretá-las, então, é crucial. Pois, mesmo assegurados por essas leis, tendemos a enxergar com preconceito a questão da inclusão. Mantoan (2003) considera que grande parte das barreiras criadas por aqueles que defendem que a Educação Inclusiva refira-se apenas às pessoas com deficiência e tem origem em interpretações tendenciosas e equivocadas das leis.

Problemas conceituais, desrespeito a preceitos constitucionais, interpretações tendenciosas de nossa legislação educacional e preconceitos distorcem o sentido da inclusão escolar, reduzindo-a unicamente à inserção de alunos com deficiência no ensino regular. (MANTOAN, 2003, p. 22)

Uma escola inclusiva, precisa considerar que as diferenças humanas são normais e que essa diversidade deve ser enxergada de modo a enriquecer o processo educacional. A inclusão provoca na comunidade escolar a necessidade de reestruturação do sistema educacional, primando pela educação de qualidade a todo (MENDES, 2002). Vale ressaltar que, embora o foco dessas mudanças referidas nessa pesquisa se concentre ao que diz respeito à comunidade escolar, é necessário ir além e propor uma transformação social livre de preconceito e discriminação. Para isso, é imprescindível que a Educação seja para todos de fato, permitindo assim que cada indivíduo acesse sua plenitude por meio dela e tenha as condições necessárias de exercer sua cidadania em direito de igualdade. 


\subsection{Alunos com necessidades educacionais especiais (NEEs): integrar ou incluir?}

Neste tópico, pretende-se apresentar o conceito de Necessidades educacionais especiais e dialogar acerca dos pensamentos de inclusão e integração, destacando suas particularidades. Aqui, "inclusão" é sinônimo de equidade e adquire o sentido de oferecer educação de qualidade a todos. Enquanto que "integração" refere-se a inserir alunos em sala de aula comum, praticando currículos diferenciados.

Segundo as Diretrizes Nacionais para a Educação Especial na Educação Básica, consideram-se alunos com necessidades educacionais especiais aqueles que apresentam:

I - dificuldades acentuadas de aprendizagem ou limitações no processo de desenvolvimento que dificultem o acompanhamento das atividades curriculares,compreendidas em dois grupos:

a) aquelas não vinculadas a uma causa orgânica específica;

b) aquelas relacionadas a condições, disfunções, limitações ou deficiências;

II - dificuldades de comunicação e sinalização diferenciadas dos demais alunos,demandando a utilização de linguagens e códigos aplicáveis;

III - altas habilidades/superdotação, grande facilidade de aprendizagem que osleve a dominar rapidamente conceitos, procedimentos e atitudes.

(BRASIL, 2001, s.p.)

A escola deve realizar a avaliação do aluno para identificar suas necessidades especiais. Para isso, deve contar com assessoramento técnico, experiência de seu corpo docente e apoio da família. Nota-se que esse diagnóstico depende de um conjunto de fatores, no entanto pode e deve ser provocado pela instituição. Asdiretrizes ainda preveem o acompanhamento pedagógico, sempre que necessário, por professor da especializado. Entretanto, nem sempre a escola dispõe de um diagnóstico sobre as necessidades educacionais especiais que os alunos precisam. O professorregente, muitas vezes, por estar em contato direto com o aluno, é o primeiro a perceber suas dificuldades de aprendizagem. Neste caso, é importante que não tente diagnosticar o aluno, mas que encaminhe para quea equipe gestora proceda quanto à sua avaliação.

Independente doslaudos oficiais que atestem as necessidades educacionaisespeciais dos alunos, o professor precisa "arregaçar as mangas" e preparar suas aulas visando ensinar a turma toda. Sobre essa questão, Mantoan (2003) alerta sobre os riscos de se antecipar um diagnóstico de um aluno só porque ele se mostra diferente dos demais. 
A maioria dos alunos das classes especiais é constituída pelos que não conseguem acompanhar os seus colegas de turma, os indisciplinados, os filhos de lares pobres, os filhos de negros e outros. Pela ausência de laudos periciais competentes e de queixas escolares bem fundamentadas, esses alunos correm o risco de serem admitidos e considerados como PNEE. (MANTOAN, 2003, p. 21)

Conformeaprofundou-se a pesquisa bibliográfica e também com a experiência em sala de aula, ficoucada vez mais evidente a importância das escolas se firmarem, de fato, em uma orientação inclusiva. Esse movimento vai muito além do agrupamento de alunos com e sem necessidades educacionais especiais. Afinal, esse pensamento evoca outro conceito já sobreposto, que é o da "Educação Integrativa". Nesse modelo de ensino, a pessoa com deficiência ou que necessita de atenção especial frequenta os mesmos ambientes de ensino que os alunos regulares, porém participam de atividades distintas do restante do grupo. $\mathrm{Na}$ maioria das vezes com "currículos pobres" (FREIRE, 2008), atividades mais "fáceis" que as do restante, ou seja, subestimando ebaixando a expectativa em relação às suas capacidades. Nessa configuração, o aluno está integrado, mas não incluído.

O ensino do Teatro, temática deste trabalho, assume nesse ponto um caráter especial de inclusão, uma vez que tem em sua essência o princípio da diversidade e da relação do indivíduo com o coletivo. Assim, os jogos teatrais e dramáticos permitiriam aos alunos que comungassem da criatividade, do pensamento lúdico, da autonomia e do desenvolvimento de critérios de gosto pessoal (BRASIL, 1998).

Glat e Nogueira (2003) rememoram que nosso sistema de ensino não foi preparado para receber alunos que fujam da "normalidade", sejam eles alunos com deficiência ou não. Isso quer dizer que o ambiente escolar ainda é conservador e tende a "excluir" todos aqueles alunos que não se enquadrem nos padrões comportamentais. Assim, o ensino divide os alunos em "normais", sendo aqueles que correspondem a este ambiente tradicional de ensino e "anormais" ou "especiais" aqueles alunos que não se enquadram.

É fato constatado que o nosso sistema regular de ensino, programado para atender àquele aluno "ideal", com bom desenvolvimento psicolinguístico, motivado, sem problemas intrínsecos de aprendizagem, e oriundo de um ambiente sócio-familiar que lhe proporciona estimulação adequada, tem se mostrado incapaz de lidar com o número cada vez maior de alunos que, devido a problemas sociais, culturais, psicológicos e/ou de aprendizagem, fracassem na escola. (GLAT et NOGUEIRA, 2003, p. 135) 
Essa constatação é evidente uma vez que admite um problema original do sistema de ensino, que é a predileção da comunidade escolar por alunos comuns em detrimento daqueles que apresentam maior dificuldade de aprendizagem. Esse ambiente "ideal" é também utópico e fadado ao fracasso social, já que acaba por excluir aqueles alunos que mais necessitam de atenção especial. Esse mal-estar acontece justamente pelo fato dos professores não serem preparados, desde os cursos de formação, para lidar com esse aluno que foge dos padrões de "normalidade", em especial, os alunos com deficiência ou mesmo aqueles com necessidades educacionais especiais.

Incluir não é fazer de conta que as diferenças não existem e todos devem ser tratados iguais. Pelo contrário, todos devem ser vistos diferentemente, porque ninguém é igual. E isso é bom, porque enriquece o aprendizado ao passo em que conduz o ensino de modo a proporcionar a todos o mesmo objetivo. “Incluir é abandonar estereótipos” (WERNECK, 1997, p. 56). Essa breve citação de Werneck nos alerta sobre a importância de mudarmos nossa perspectiva originada a partir do aluno "ideal", aquele sem nenhuma dificuldade de aprendizagem, com disciplina e sem deficiência.

Uma aula de Teatro para toda turma deve incluir a todos e, caso isso não seja possível, deve-se ao menos perceber onde reside essa dificuldade pedagógica. É a escola que não dispõe de recursos para efetivação da inclusão educacional? Ou são os pais que não oferecem o acompanhamento necessário para o desenvolvimento do aluno? Ou seria a falta de professores da educação especial para dar suporte às aulas de Teatro? Ao menos esse diagnóstico o professor de Teatro deve estar preparado para realizar ao entrar em uma escola, do contrário, ficará a mercê dos estereótipos, do senso comum e dos clichês de uma pedagogia que não condiz mais com a sociedade inclusiva. A seguir, propõe-se o diálogo sobre essas e outras questões cruciais para o professor. 


\section{CAPÍTULO 2 - A EXPERIÊNCIA DE ESTÁGIO E O ENSINO DO TEATRO NAS ESCOLAS: UMA PROPOSTA INCLUSIVA?}

Ainda hoje, muito se discute sobre o papel da arte-educação nas escolas, em especial o do Teatro. É necessário lembrar que, de acordo com os Parâmetros Curriculares Nacionais de Arte, no Brasil, até a metade do século XX as disciplinas de Desenho, Trabalhos Manuais, Música e Canto Orfeônico estavam inseridas nos programas das escolas primárias e secundárias. Entretanto, concentravam-se na transmissão dos padrões culturais predominantes da época. A escola tradicional estava mais interessada em preparar o aluno para um exercício imediatista de habilidades e “dons artísticos”, do que em trabalhar a Arte enquanto expressão, a fim de desenvolver o pensamento crítico dos alunos. A dança e o teatro só apareciam quando requisitadas para comemorações de festividades: “O teatro era tratado com uma única finalidade: a da apresentação. As crianças decoravam os textos e os movimentos cênicos eram marcados com rigor” (BRASIL, 1997, p. 22).

A partir da década de 70, a arte foi inserida no currículo escolar como "Educação Artística", mas não era considerada uma disciplina, mas sim uma "atividade educativa" na qual prevalecia a figura do professor "polivalente", aquele que precisava abordar diversas áreas artísticas como música, artes visuais e artes cênicas.

A partir da década de 90, os esforços dos militantes da arte-educação reverberam com a homologação da Lei de Diretrizes e Bases, que passa a considerar o ensino de Arte obrigatório nas escolas: “O ensino da arte, especialmente em suas expressões regionais, constituirá componente curricular obrigatório da educação básica” (BRASIL, 1996, s.p).O movimento arte-educação então ganha força e legitimidade. O ensino da arte é introduzido nas escolas como disciplina de Arte e não mais Educação Artística e, a partir dos Parâmetros Curriculares Nacionais de Artes, reconhece-se suas diferentes modalidades: Música, Visuais, Dança e Teatro. A Arte passa a ser reconhecida como área de conhecimento com conteúdos próprios e não apenas suporte para outras disciplinas nas escolas (BRASIL, 1997).

Em Mato Grosso, a falta de professores com formação em Arte, em particular em Teatro, contribui para que persista o paradigma do professor "polivalente". Ou ainda, que 
aulas de Teatro sejam ministradas por professores de outras áreas de conhecimento. Em meus estágios, por exemplo, não tive a oportunidade de observar professoreslicenciadosnesta área ou em Arte com habilitação em Teatro. Dos três estágios que realizei na educação básica, apenas um desses docentes era graduado em Arte, porémcom habilitação em Música. Os outros dois professores, embora se propusessem a ministrar aulas de Teatro aos alunos, eram de outros componentes curriculares. Koudela (2002) ressalta esse resquício deixado pelo modelo tradicional de ensino, que ainda reverbera no país em relação à dificuldade de se contratar professores com formação em Arte e habilitados em suas linguagensartísticasespecíficas:

Se a implantação da Educação Artística (currículo em vigor anterior aos PCN) implicou na improvisação de professores no início dos anos 1970, ainda hoje os sistemas de ensino enfrentam dificuldades quanto à contratação de especialistas. A carência de profissionais existe nas cidades do interior e até mesmo nas escolas das capitais da grande maioria dos estados. (KOUDELA, 2002, p. 238)

É importante enfatizar essa questão, pois ela acaba ecoando a respeito do lugar em que o Teatro deve ocupar nas escolas e até mesmo em políticas públicas de valorização profissional. Em Mato Grosso, isso ficou evidente com a publicação do edital do concurso público, realizado pela Secretaria Estadual de Educação para professor de Arte da rede estadual. No texto original do edital, só eram considerados os diplomas de professores formados em Educação Artística com habilitação em Artes Plásticas e/ou Música, conforme publicado no quadro de requisitos para o cargo:

Diploma, devidamente registrado, ou Certificado acompanhado de Histórico Escolar, de conclusão de curso de graduação de nível superior de Licenciatura Plena em Educação Artística com habilitação em Artes Plásticas e/ou Licenciatura Plena em Educação Artística com habilitação em Música, fornecido por instituição de ensino superior reconhecida pelo Ministério da Educação (MEC). (CONCURSO PÚBLICO, EDITAL Nº. 01/2017 - 03 DE JULHO DE 2017, p. 2) 
Foi necessária a mobilização dos arte-educadores para que o texto do edital fosse alterado e inseridas as habilitações em Artes Visuais, Dança e Teatro, conforme estabelecem os Parâmetros Curriculares Nacionais. A seguir, o texto retificado:

Licenciatura Plena em Educação Artística com habilitação em Artes Plásticas, Artes Visuais, Dança, Música, Teatro, fornecido por instituição de ensino superior reconhecida pelo Ministério da Educação (MEC). (CONCURSO PÚBLICO, EDITAL Nº 01/2017 - 03 DE JULHO DE 2017, RETIFICAÇÃO N 1 , p. 2)

Este equívoco no edital do concurso público reforça a necessidade de mais professores habilitados nas diversas linguagens artísticasno estado, uma vez que o aluno, no atual modelo predominante nas escolas públicas estaduais, não pode optar por qual modalidade artística deseja estudar, assim como não conhece a habilitação de seu professor de Arte. O modelo ideal, então, seria aquele em que o aluno pode escolher qual modalidade artística deseja cursar em sala de aula, tal como acontece nos Centros Federais de Educação Tecnológica (CEFET) e Institutos Federais de Educação, Ciência e Tecnologia (IF). Desse modo, o aluno teria acesso a uma maior diversidade de opções artísticas, exercendo assim seu protagonismo.

Embora todas as modalidades sejam importantes, oferecer ao aluno opções de escolha faz com que ele aprenda a reconhecer as formas artísticas e possa, a partir disso, aplicar sua autonomia no processodeensino-aprendizagem. Os Parâmetros Curriculares Nacionais reforçam a importância do ensino de Arte na educação básica e com isso buscam promover no aluno o acesso ao exercício da sua sensibilidade, percepção, reflexão e imaginação. A linguagem poética da Arte confere ao aluno sentido às suas experiências.

A educação em arte propicia o desenvolvimento do pensamento artístico e da percepção estética, que caracterizam um modo próprio de ordenar e dar sentido à experiência humana: o aluno desenvolve sua sensibilidade, percepção e imaginação, tanto ao realizar formas artísticas quanto na ação de apreciar e conhecer as formas produzidas por ele e pelos colegas, pela natureza e nas diferentes culturas. (BRASIL, 1997, p.19) 
Mais uma vez, conjecturando o que seria a escola ideal para o ensino de Arte, o aluno deveria ser apresentado às modalidades de Música, Visuais, Dança e Teatro e, a partir desse contato, escolher aquela que lhe despertasse mais interesse. Entretanto, como o foco dessa pesquisa é o ensino do Teatro, destacam-se seus predicativos.

O Teatro é uma expressão artística completa e remonta aos primórdios da humanidade. Seja por meio de narrativas corporais do homem primitivo sobre seus feitos, dos rituais de tribos antigas, o teatro sempre esteve presente. A dramatização está presente na criança desde suas primeiras buscas por representar a realidade que a circunda. O jogo simbólico do teatro permite não apenas descobertas individuais, mas coletivas. Ao realizar atividades teatrais em grupo, o aluno se integra ao coletivo, amplia sua percepção de mundo e desenvolve sua humanidade a partir de preceitos básicos como o respeito ao direto à diversidade, conforme reforça os Parâmetros Curriculares Nacionais:

No plano do coletivo, o teatro oferece, por ser uma atividade grupal, o exercício das relações de cooperação, diálogo, respeito mútuo, reflexão sobre como agir com os colegas, flexibilidade de aceitação das diferenças e aquisição de sua autonomia como resultado do poder agir e pensar sem coerção. (BRASIL, 1997, p.58)

Quando se fala de Educação Inclusiva, o Teatro passa então a ser protagonista uma vez que atua na interseção das questões que tangem as experiências individuais e a diversidade, permitindo ao jovem o desenvolvimento da sua criatividade, da educação estética, da prática artística, do exercício das relações interpessoais e do reconhecimento das diferenças. Por meio dos jogos teatrais, o aluno aprende a desenvolver em grupo sua imaginação e a consciência do “como se”, combinando a dramatização com a prática e observação de regras (KOUDELA, 2002).

Ao tempo em que se enfatiza as especificades do Teatro enquanto modalidade de Artee como ferramenta de inclusão, não se pode negar a importância de uma formação completa de arte-educadores capazes de interagir com outras áreas de conhecimento, oferecendo ao aluno uma formação multidisciplinar. No tópico a seguir, tratarei com mais 
ênfase essa questão e abordarei a noção de jogos no Teatro e sua importância enquanto potencializadores do ensino-aprendizagem.

\section{1 - A noção de jogo e drama no Teatro}

As crianças e os animais brincam porque gostam de brincar, e é precisamente em tal fato que reside sua liberdade. (Johan Huizinga)

Segundo o filósofo Johan Huizinga (1999), o jogo é uma capacidade inerente ao ser humano, que precede até mesmo sua cultura, já que existem evidências de sua manifestação antes mesmo das concepções de língua e civilização. No entanto, não é uma exclusividade da espécie humana, pois é sabido que animais também jogam, brincam. Um felino se esconde atrás da porta e espera seu irmãozinho gato passar para surpreendê-lo com um salto. Os dois rolam e se mordem sem se machucar, pois ambos, de algum modo, sabem que estão brincando.

Diríamos, então, que, na sociedade primitiva, verifica-se a presença do jogo, tal como nas crianças e animais, e que, desde a origem, nele se verificam todas as características lúdicas: ordem, tensão, movimento, mudança, solenidade, ritmo, entusiasmo. Só em fase mais tardia da sociedade o jogo se encontra associado à expressão de alguma coisa, nomeadamente aquilo a que podemos chamar "vida" ou "natureza". (HUIZINGA, 1999, p. 21).

Então, o que seria o jogo? Huizinga (1999)alerta sobre a existência de diversas teorias a respeito e recomenda a consulta de autores como os filósofos H. Zondervan (1928) e F. J. J. Buytendijk (1932). Uma dessas teorias, segundo o autor, defende o jogo como uma necessidade de "descarga de energia vital". Como se o ser humano precisasse gastar essa energia superabundante por meio dos jogos. Outra teoria que Huizinga apresentadiz que o jogo vem de certo prazer no "instinto de imitação". Ou ainda, de uma preparação do jovem para as necessidades da vida adulta. Existe ainda uma teoria que diz que o jogo nasce da 
necessidade do ser humano de expurgar desejos nocivos, como a violência, ou "uma ficção destinada a preservar o sentimento de valor pessoal" (p. 4).

Qualquer uma das teorias acima poderia ser aceita sem que se satisfizesse, de fato, a questão central: por que brincamos? Porém, há certo consenso em pressupor que o jogo, a brincadeira, propõe uma realidade lúdica, paralela e auto-suficiente. Quando se joga, o jogo é tudo o que existe e o exterior não importa. Um lapso temporal, uma suspensão da realidade, enfim, "a realidade do jogo ultrapassa a realidade da vida humana" (HUIZINGA, 1999, p. 6).

O jogo é uma atividade ou ocupação voluntária, exercida dentro de certos e determinados limites de tempo e de espaço, segundo regras livremente consentidas, mas absolutamente obrigatórias, dotado de um fim em si mesmo, acompanhado de um sentimento de tensão e de alegria e de uma consciência de ser diferente da "vida quotidiana" (HUIZINGA, 1999, p. 33).

Em Teatro, quando se fala em jogos, evoca-se todo o caráter lúdico que o significado da palavra pressupõe, que tanto pode se referir ao próprio teatro quanto às práticas educacionais utilizadas para lecionar esta linguagem artistica.

Embora pareçam similares, Maria Lúcia Pupo (2001) descreve o jogo teatral (theater game), introduzido na década de sessenta pela teatróloga Viola Spolin, como um jogo cênico improvisacional realizado em grupo e com regras pré-estabelecidas e consentidas coletivamente. O jogo dramático (jeu dramatique), de origem francesa, foi formulado a partir de Charles Dullin e Léon Chancérel, que criaram um jogo tambémimprovisacional com a intenção de aperfeiçoar os trabalhos artísticos da época (p. 182). Então, o jogo teatral de Viola Spolin tem sua origem pedagógica e o jogo dramático tem na concepção francesa o objetivo da investigação artística. Entretanto, ambos têm como finalidadea experiência estética (sensorial) dos jogadores, conforme reforça Pupo (2001):

Ambos têm na platéia - interna ao grupo de jogadores - um elemento essencial para a avaliação dos avanços conquistados pelos participantes. Prescindem da noção de talento ou de qualquer pré-requisito anterior ao próprio ato de jogar e apresentam propostas de caráter estrutural, derivadas da linguagem do teatro, que permitem a formulação, pelo próprio grupo, das situações, temas, desejos, que quer trazer à tona.(p. 182) 
Ainda sobre a comparação entre jogo teatral e jogo Dramático, Pupo (2001) evidencia seus objetivos comuns, na medida em que ambos funcionam como consciência estética e praxis artística.

De modo análogo ao jogo teatral, o jogo dramático na acepção francesa do termo visa a fazer com que participantes de qualquer idade adquiram consciência sobre a significação no teatro e possam, através dele, emitir um discurso sobre o mundo. (p. 182)

O Dicionário de Teatro de Patrice Pavis (2017) não traz nenhum verbete acerca do jogo teatral, apenas a respeito do jogo dramático, que segundo o autor é:

Prática coletiva que reúne um grupo de "jogadores" (e não de atores) que improvisam coletivamente de acordo com um tema anteriormente escolhido e/ou precisado pela situação. Portanto, não há mais separação entre ator e espectador, mas tentativa de fazer com que cada um participe da elaboração de uma atividade (mais que de uma ação) cênica, cuidando para que as improvisações individuais se integrem ao projeto comum em curso de elaboração. (p. 222)

Biange Cabral (2008) ressalta a diferença da concepção francesa (jeudramatique) da concepção inglesa (child drama) disseminada por Peter Slade (1978) no final da década de setenta com a publicação de seu livro Na Intricuctionto a Child Drama, que no Brasil foi traduzido como O Jogo Dramático Infantil (p. 37-38). Segundo a autora, o conceito que Slade defendia eu seu livro se aproximava mais da ideia de "faz de conta" que as crianças realizam enquanto brincam, sem regras e sem a presença de plateia ou mesmo sem a intenção de se comunicar algo para uma audiência externa à brincadeira, como acontece no jogo de Spoline no de Dullin:

“Child Drama” não inclui regras de nenhum tipo, nem mediação do professor ao nível do desenvolvimento da atividade, não apresentando característica de jogo, a não ser que o traduzíssemos por ‘jogo simbólico’. (CABRAL, 2008, p. 37) 
Portanto, a concepção brasileira de jogo dramático que derivou a partir do conceito do child game de Peter Slade está mais relacionada ao "jogo simbólico" do que ao "jogodramático" propriamente dito. Por isso, os conceitos que vamos trabalhar nessa pesquisa acerca dos jogos realizados durante as aulas de Teatro estão umbilicados ao theater game de Viola Spolin e ao jeudramatique de Dullin e Chancérel.

Cada tipo de jogo tem seu contexto e sua utilidade e cabe ao professor de Teatro definir qual a melhor opção para trabalhar com os alunos. Em minhas aulas durante o estágio, optei por trabalhar as duas formas, pois entendo que o jogo teatral tem seu valor centrado no protagonismo do aluno enquanto indivíduo e sua relação com o coletivo. Enquanto o jogo dramático tem em seu caráter investigativo o ponto de partida ideal para realização de trabalhos artísticos, construção de personagens e montagens teatrais.

Outra manifestação cênica que procurei abordar em sala de aula foi o "drama" como método de ensino de Teatro. Biange Cabral (2008) aponta que esse método surgiu na década de cinquenta, sendo difundido pela inglesa Dorothy Heathcote. O drama se distingue dos jogos teatrais e dramáticos devido a sua preocupação com a "forma" teatral e pressupõe mais intervenção do professor com abordagem "enciclopédica", ou seja, com mais quantidade e qualidade de informações em relação às noções de espaço, ao contexto e às situações investigadas; com intervenções referentes à estrutura e fornecimento de signos visuais como textos e imagens. Embora haja maior intervenção do professor na dramatização, o texto é todo de autoria dos alunos e todas as interações do professor são desconstruídas pelos educandos, passando a ser apenas estímulos, mediações para suas criações (p. 38).

Quer se utilize o jogo teatral, o jogo dramático ou o drama, o professor de Teatro precisa entender o contexto político, cultural e social nos quais seus alunos estão inseridos. Sua interação com diversas linguagens (texto, corpo, música, imagem entre outras) é imprescindível, o que se aproxima do caráter multidisciplinar, que segundo Luciana Hartmann (2009), busca o relacionamento de diversas disciplinas sem que estas, no entanto, percam suas especificidades. 
Convido para continuar a leitura do próximo tópico, onde tratarei das metodologias utilizadas em sala de aula durante meu estágio em Teatro, procurando demonstrar por meio de exemplos práticos o desenvolvimento e as apreensões dos alunos.

\section{2 - Memórias de um Professor de Teatro na educação formal com alunos com necessidades educacionais especiais}

A memória é um sino original — Festa e Funeral Emily Dickinson

Para elaborar este capítulo, realizei uma pesquisa documental, revisitando meus diários de bordo e meu artigo final do Estágio 3 do curso de Licenciatura em Teatro, no qual tive a oportunidade de trabalhar com alunos com necessidades educacionais especiais.

Em meu terceiro estágio supervisionado, trabalhei em uma escola pública de ensino em tempo integral. A Escola Estadual Antônio Epaminondas é umas das quinze escolas que foram contempladas com o projeto pedagógico "Escola da Escolha", que em Mato Grosso tem sido chamado de "Escola Plena". Nela, o aluno e seu projeto de vida são defendidos como tema central. Segundo o Caderno de Formação do Ensino Médio ${ }^{2}$, os princípios educativos da escola são: o Protagonismo; os Quatro Pilares da Educação (aprender a conhecer, aprender a fazer, aprender a conviver, aprender a ser); a Pedagogia da Presença e a Educação Interdimensional. As Escolas Plenas foram instituidas por decreto e receberam investimento do Governo para ampliarem sua jornada de trabalho. Nelas, os alunos estudam em tempo integral, tomam café da manhã e almoçam na escola. Ou seja, passam mais tempo dentro da escola do que em suas próprias casas, com suas famílias. É um projeto interessante e pioneiro em Cuiabá, cidade sede da escola.

\footnotetext{
${ }^{2}$ Caderno entregue pelo Ministério da Educação (Brasil) a todas as escolas pertencentes ao projeto pedagógico Escola da Escolha, de ensino em tempo integral.
} 
Além disso, a Escola Epaminondasiniciou recentemente um projeto de aulas eletivas chamado de "Balaio das Artes", que tem por objetivo dispor à escolha dos alunos propostas de aulas complementares além das obrigatórias na matriz curricular.

\begin{abstract}
Baseado em ideias que retratam a cultura de forma generalizada, o tema sugere teorias e práticas na aprendizagem multidisciplinar das áreas de Ciências da Natureza, Ciências Humanas e Linguagem. Propondo uma relação clássica dos estudos com o cotidiano. As áreas a serem trabalhadas se dividem em: Encename(Teatro), Inspira-me (Artes Plásticas), Encanta-me (Música e instrumentos), Movimenta-me (Dança), Envolva-me (Escultura regional). ${ }^{3}$
\end{abstract}

O objetivo das eletivas é gerar a interdisciplinaridade entre as diversas áreas de conhecimento e, em especial, unir as Ciências da Natureza, Ciências Humanas e Linguagens, promovendo o diálogo com o cotidiano dos alunos.

\begin{abstract}
Desenvolver habilidades individuais de cada aluno, além de promover o trabalho em equipe, despertando a curiosidade, preparando-os para a construção e elaboração de seu próprio conhecimento com autonomia e criticidade diante de contexto que permeia a interpretação, a criação de personagem, o estudo do som, o movimento do corpo, a absorção de texto, a criação de uma obra, a linguagem teatral, ritmo da dança, enfim, propondo uma aprendizagem inovadora e satisfatória a todos os educandos. ${ }^{4}$
\end{abstract}

Aos alunos, então, foram oferecidas as opções de escolha entre aulas de Teatro, Artes Plásticas, Músicas e Instrumentos Dança e Esculturas Regionais. Se por um lado existia a empolgação de fazer parte de um projeto novo, que permitisse traçar caminhos nunca trilhados dentro daquela comunidade escolar, tendo autonomia para gerir as aulas conforme meu discernimento, por outro, sentia-me com a responsabilidade de garantir que esses alunos, professores e comunidade, tivessem uma vivência enriquecedora em relação ao Teatro. Aliás, um ponto que muito me instigou é que, por se tratar de uma disciplina eletiva, os alunos, dentro das alternativas que tiveram,optarampelo Teatro.Aexpectativa era de que todos os alunos estivessem nas aulas porque escolheram estar ali e não porque foram obrigados pelo sistema escolar.

\footnotetext{
${ }^{3}$ Trecho retirado do Projeto Pedagógico da Eletiva Balaio das Artes. ${ }^{4}$ Idem.
} 
É louvável a iniciativa da escola em propor um projeto que tivesse a premissa de unir distintas áreas de conhecimentos, já que, comumente, as escolas tendem a dissociá-las e, na maioria das vezes, priorizam uma em detrimento da outra. O "Balaio das Artes" tem a presunção de mostrar que uma relação mútua entre os saberes não só é possível como podem ser potencializados ao serem combinados.

Estava ao mesmo tempo preocupado, pois meus colegas que ministraram aulas em escolas públicas possuíam narrativas nem um pouco favoráveis. Em geral, diziam sobre aindisciplina dos alunos. Tive receio de não ter domínio de sala, de não ser respeitado. Mas não foi o que aconteceu. Acredito que, das três experiências de estágio, a terceira foi a mais notável. Creio que o desafio sendo maior, maior também é a satisfação em conseguir contribuir com algo.

As aulas eletivas estavam previstas para durarem um trimestre e teriam como culminância a montagem de um espetáculo teatral do século XVII, intitulada "Oh, rei louco!", onde se previa a abrangência de "cenário, figurino, iluminação e sonoplastia executados pelos educandos". Mesmo sabendo que não conseguiria acompanhar os alunos durante todo o período de montagem, propus-me ajudá-los no que fosse necessário.

É sabido que há uma tendência das escolas, quando se trabalha com Teatro, deobjetivarem uma mostra de resultados que acaba sempre culminando na montagem de uma peça teatral à comunidade. Na escola em questão, não me pareceu ser diferente e a montagem estava prevista no projeto pedagógico da eletiva. Essa prática muito comum nas escolas é o que Joaquim Gama (2002) chama de "a polêmica entre o processo e o produto teatral" (p. 264).

Para o autor, o teatro enquanto produto tem sua origem no Ensino Tradicional, em que o que predominava eram as aulas expositivas de transmissão de conteúdo. Nesse período histórico do Brasil, que remonta ao início do século XX, o ensino da arte estava relacionado à preparação dos alunos para trabalhos manuais nas fábricas. Assim, se buscavam treinar as habilidades motoras, a memória, a visão, o gosto e o senso moral. Nessa mesma época, alguns estabelecimentos de ensino utilizavam o teatro como métodos de habilitar os alunos para animar festas com apresentações em datas comemorativas sem que se envolvessemnenhum entendimento do texto dramático. Desta forma, procuravam sempre aqueles alunos mais 
“desinibidos” para decorar as falas e apresentar em frente ao público, fomentando a ideia de "talento" em detrimento daqueles de personalidade mais introspectiva (GAMA, 2002,p. 265).

O Teatro, enquanto processo, surge no Brasil por volta da década de sessenta com a Pedagogia Nova, trazida da Europa e dos Estados Unidos. Nessa nova proposta, o objetivo principal era trabalhar nos alunos a auto-expressão. O professor não deveria ensinar técnicas de teatro, mas liberar a criatividade do aluno para que ele pudesse se expressar. Assim, se enfatizava o processo e não o produto. Entretanto, apesar dos avanços quea nova ideia trouxe para a Pedagogia Tradicional, a supervalorização do teatro enquanto processo enfrenta críticas por ignorar, muitas vezes, "a sistematização do ensino do teatro enquanto linguagem artística" ou mesmo "enquanto área do conhecimento humano". (GAMA, 2002, p. 266).

Gama (2002)diz que é possível criar um ensino de teatro que se utilize do produto, desde que seja oferecido um espaço propício à experiência criativa. Ou seja, o produto pode ser trabalhado também enquanto processo se o professor mediar as questões relacionadas à criatividade, à auto-expressão e às criações coletivas. Desse modo, as discussões a respeito de qual modelo é o ideal para se trabalhar em sala de aula são minimizadas na medida em que se reconhece a importância de cada um deles.

A concepção moderna do ensino da Arte na escola propõe que o Teatro seja
encarado como área específica do conhecimento humano e não como uma simples
atividade que venha a preencher os momentos sociais e de lazer da escola. Dessa
forma, processos e produtos tornar-se-ão não dicotomizados, gerando processos
investigativos que possibilitarão aos alunos e aos professores uma compreensão
maior dos elementos envolvidos na Arte Teatral. (GAMA, 2002, p. 269)

Como citado em linhas anteriores, a escola na qual realizei minha pesquisa tinha fortes traços do modelo de Ensino Tradicional. Isso foi evidenciado pelo modo como a coordenação pedagógica me instruiu a trabalhar conteúdos "expositivos" com os alunos, relacionados a "História do Teatro", além de prever como conclusão da disciplina eletiva um produto final: a montagem de um espetáculo. Entretanto, não cabia a eu tecer nenhum juízo de valor em relação a isso, mas sim promover a mediação dos alunos e do processo teatral dentro da proposta da disciplina. 
Ou seja, assumi ali o papel de incentivador dos educandos para que alcançassem os objetivos do projeto pedagógico da disciplina. Busquei mesclar minhas aulas com conteúdo expositivo e aulas práticas com jogos, trabalhando sempre a correlação entre essas duas didáticas. Sempre que expunha um slide sobre algum conteúdo, buscava relacioná-lo com o jogo teatral trabalhado ou mesmo a leitura de algum texto pelos alunos.

As aulas começaram e a turma da eletiva de Teatro era composta por cerca de 15 alunos do $1^{\mathrm{o}}$ ao $3^{\circ}$ anos do Ensino Médio, entre meninos e meninas, com idades que variavam de 13 a 25 anos, sendo sua maioria na faixa etária entre 15 a 17 anos. Alunos que escolheram esta linguagem artística para cursarem e que nunca tiveram nenhuma experiência com Teatro. Pensei, então, que isso significassea existência de expectativas; predileção desses alunos pelo Teatro. Então, meu ponto de partida foi uma breve entrevista dos alunos para conhecer qual a ideia de teatro que eles tinham em mente e qual a expectativa em relação às aulas. A partir dessa investigação, acreditei que pudesse elaborar e ajustar melhor minhas aulas ao contexto dos alunos.

No entanto, percebi que seria necessário mais tempo para conhecê-los melhor. Eles não me dariam tudo o que precisava de prontidão. Esse contato foi cortado pela necessidade que senti, orientado pela escola, de falar um pouco sobre a história do teatro. Interrompi o círculo e, a partir daí, optei por uma aula mais expositiva.

Enquanto eu utilizava o projetor multimídia para exibir uma apresentação sobre a tragédia e a comédia no Teatro Grego, expus o fato de que, naquela época, as mulheres não podiam participar das apresentações teatrais, pois essa atividade só era permitida aos cidadãos e as mulheres, no geral, não eram consideradas cidadãs. Perguntei a eles o que eles achavam disso, eis que uma aluna não titubeou em externar sua indignação: "eu acho isso um absurdo, professor. Isso é machismo!". Complementei o fato, explanando brevemente sobre a importância da presença das mulheres em todas as áreas, sejam elas políticas, culturais ou sociais. Esse fato foi interessante, pois demonstrou que mesmo em momentos de aulas expositivas de Teatro é possível suscitar discussões e reflexões nos alunos.

Os alunos se mostraram disciplinados, prestavam atenção à exposição do conteúdo e até participavam dele quando provocados, embora eu não soubesse nesse momento se todos 
estavam conseguindo assimilar as informações que eu expunha, uma vez que não eram todos que interagiam, apenas os que demonstravam maisdesenvoltura.

Após concluir o momento expositivo, propus um jogo teatral chamado "jogo das máscaras", fazendo referência às personas gregas. Esse jogo é uma criação minha a partir do jogo tradicional "morto ou vivo". Os alunos se colocavam em pé na minha frente e, ao meu comando, deveriam reproduzir uma das seis expressões faciais básicas: raiva, nojo, medo, alegria, tristeza e surpresa. Aqueles que iam errando, se confundindo com os comandos iam abandonando o grupo.

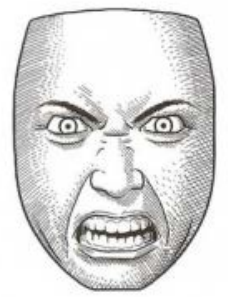

RAIVA

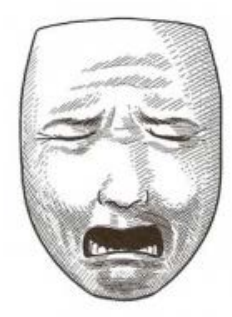

TRISTEZA

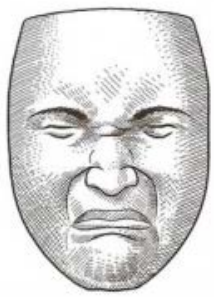

NOJO

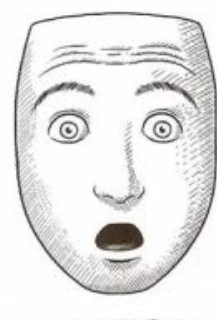

SURPRESA

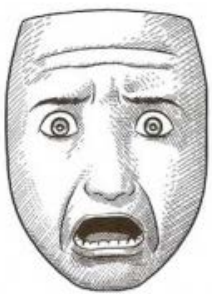

MEDO

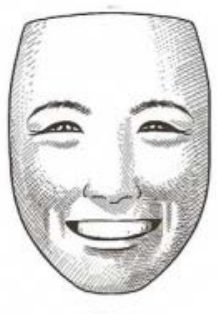

ALEGRIA

Imagem 1 - As seis expressões faciais básicas ${ }^{5}$

Durante esse jogo, percebi que Amanda demonstrava dificuldade em acompanhar meus comandos. Não realizava nenhuma das expressões, apenas se colocava ali, junto aos colegas, sem jogar. Embora seu rosto demonstrasse simpatia, sempre com um sorriso, percebi sua resistência em reproduzir as emoções em sua face. Mas as regras do jogo eram claras: quem não conseguisse acompanhar deveria deixar o grupo e se juntar a mim até que só restasse um aluno.

\footnotetext{
${ }^{5}$ Imagem disponível em http://1.bp.blogspot.com/sQptds2xc6o/Tqi9ref_owI/AAAAAAAAOaU/bKGP3zRukAw/s1600/02_2.jpg
} 
O jogo das máscaras propunha um caráter competitivo, como todo jogo. Afinal, qual a graça de jogar se não for pela chance de vencer? Ainda que seja vencer as próprias dificuldades. "Em todos os jogos, é muito importante que o jogador possa gabar-se a outros de seus êxitos" (HUIZINGA, 1999, p. 57). Busquei não cessar a participação daqueles alunos eliminados. Estes, por sua vez, deveriam se colocar ao meu lado e ajudar na identificação dos colegas que reproduziam as expressões faciais.

Nos dias que se seguiram, passei a entender melhor o contexto em que estava inserido. Alguns alunos novos na eletiva foram chegando na aula. Foi então que eu pedi para se apresentarem, dizendo seu nome em voz alta. Depois de insistir para uma aluna falar seu nome, recebi a resposta de sua irmã e colega de turma, "professor, o nome dela é Beatriz". Insisti: "deixa ela falar o próprio nome". "Mas professor, ela não fala". Recompondo-me do constrangimento e dos risos nervosos da turma, questionei "ela é surda? Se comunica por Libras?". Beatriz acenou a cabeça negativamente e a irmã me informou: "não, professor, ela escuta, mas não consegue falar". Pelo pouco conhecimento que tinha à época, pressupus que ela tivesse alguma "deficiência" na fala. Senti-me impotente. Pensei "e agora? Será que Beatriz vai conseguir acompanhar a turma?".

Mas Beatriz não foi a única que me preocupou. Carol, sua irmã, também não parecia conseguir apreender minhas instruções. Falava sem articular bem as palavras, o que comprometia sua dicção e tinha claras dificuldades de leitura.

Beatriz e Carol sempre sentavam juntas com Amanda, que por sua vez também chamou minha atenção. Mais velha que o restante da turma, Amanda sempre se queixava, "não estou entendendo, professor", ao mais simples exercício. No início, senti certa impaciência, pois pensei que ela fosse algum tipo de pessoa preguiçosa. Eu não percebia que esse meu pensamento tinha origem no preconceito em não entender que essas dificuldades de aprendizagem nada têm a ver com displicência ou falta de inteligência, como bem assinala Corinne Smith (2001) em seu livro Dificuldades de Aprendizagem de A a Z: "Ano após ano, muitos desses jovens são erroneamente classificados como tendo baixa inteligência, insolência ou preguiça" (p. 14).

Em outra ocasião, emsala de aula, realizamos a leitura do conto "Sem novidades do front", de Marina Colasanti. Perguntei aos alunos quem gostaria de ler. Alguns acenaram, 
condordando em participar da atividade e distribuí os parágrafos entre eles. Promovi, em seguida, uma roda de discussão para saber o que a turma havia apreendido da leitura. Ficou nítido o desnivelamento da turma. Enquanto uns conseguiam promover interpretações aprofundadas do conto, Amanda disse não ter entendido "nada". Eu estimulei: "mas você não entendeu nadinha do que eu li? Lembra quem era a personagem da história?". Ela respondeu "não, professor". A turma sempre intercalava esses momentos com um tipo de riso nervoso.

Neste ponto, faz-se importante lembrar que as Diretrizes Nacionais para a Educação Especial na Educação Básica (BRASIL, 2001)caracterizam como alunos com necessidades educacionais especiais aqueles com "dificuldades acentuadas de aprendizagem" sejam essas vinculadas a causas orgânicas ou não (Art. $5^{\circ}$ ). Mesmo não me atentando a essas diretrizes, decidi optar por aulas mais inclusivas, nas quais eu pudesse contar com a participação de todos. Eu precisaria, ao menos por hora, privilegiar os jogos nos quais a interpretação de texto ou as funções intelectuais não fossem primordiais, mas sim a experiência sensorial. Existe uma tendência em nossas escolas em valorizar o "ler, escrever e interpretar textos", o que acaba por proporcionar um destaque daqueles alunos com maiores aptidões nessas áreas, em detrimento daqueles com dificuldades de aprendizagem, conforme descreve Ingrid Koudela (1984):

Tradicionalmente, nossas escolas são escolas de leitura. Ainda hoje, a partir da pré-
escola, a atividade fundamental da criança é aprender a ler e escrever. A criança em
idade pré-escolar "brinca”, não se atribuindo às atividades espontâneas a mesma
importância e seriedade que caracterizam o ensino primário, onde a criança começa
a ter "tarefas" a cumprir. A escola atribui um peso proporcionalmente maior à
função de acomodação da inteligência, não conferindo a mesma dimensão à
assimilação. O que se vê com frequêencia é que enquanto as funçães intelectuais
têm um progresso contínuo, na expressão artística, ao contrário, a impressão
que se tem é a de um retrocesso [...] A atividade artística é periférica ao sistema
escolar e lhe é atribuída a característica de "recreação", quando não é submetida a
exercícios de coordenação motora [...] (KOUDELA, 1984apudABREU, 2015, p. 1-
2).

Comecei a perceber que essas três alunas estavam sempre juntas. Amanda, 25 anos, já estava repetindo o $1^{\circ}$ ano do Ensino Médio pela terceira vez e era um consenso entre os professores o seu fracasso escolar. Carol, 20 anos, além das próprias dificuldades de aprendizagem, se mostrava sempre preocupada com a irmã, Beatriz, 18 anos, que não podia falar. Senti uma predisposição de minha parte em querer abandonar essas alunas com dificuldades e concentrar as aulas nos alunos que respondiam mais rapidamente às minhas 
expectativas, os ditos "alunos ideais". Eu buscava explicações em meu senso comum, que justificassem o fato dessas estudantes necessitarem que eu adaptasse minhas aulas. Sobre as dificuldades de aprendizagem, Smith (2001) reforça que elas não têm um fator gerador específico e podem ser provenientes de diversos fatores.

Para começo de conversa, o termo dificuldades de aprendizagem refere-se não a um único distúrbio, mas a uma ampla gama de problemas que podem afetar qualquer área do desempenho acadêmico. (p. 15)

Quando conversei com outros professores a respeito das alunas, soube que elas não possuíam nenhum laudo pericial que indicasse algum transtorno ou mesmo necessidades educacionais especiais. A professora de Português confidenciou que as três educandas, provavelmente, não eram "normais" e se mostrou frustrada ao admitir que Amanda teria que ser "passada de ano", pois não podia reprová-la mais uma vez. O coordenador chegou a afirmar que poderia pedir à família um laudo médico, caso eu julgasse necessário. Não se tratava de algo que eu precisasse. Eu apenas queria compreender melhor o universo daquelas alunas, saber com quem estava lidando e, talvez, confesso, me consolar com o diagnóstico, com algum rótulo que justificasse o meu fracasso diante dessas alunas. Era evidente as limitações de Beatriz, pois o problema dela era orgânico, uma disfunção na fala. Porém, Amanda e Carol não apresentavam nada aparente. Ao contrário, pareciam como qualquer outra aluna da turma, conforme explica Smith (2001), as dificuldades de aprendizagem podem ser tão discretas que os alunos não parecem ter problema algum.

Dando continuidade às atividades pretendidas, utilizei o drama em sala de aula, por meio de criação de esquetes pelos alunos, para trabalhar as questões da realidade dos educandos, a interação entre eles, e com isso aguçar o interesse pela aula e potencializar suas capacidades de solucionar problemas, já que o drama "é uma atividade criativa em grupo, na qual os participantes se comportam como se estivessem em outra situação ou lugar, sendo eles próprios ou outras pessoas" (CABRAL, 2006, p. 11).

A partir dos jogos teatrais e dramáticos, minha intenção era estimular a criatividade dos alunos, a interação, além de proporcionar o contato com a linguagem teatral. Nesse sentido, o jogo teatral se mostra bastante eficaz, como bem define Ricardo Japiassu:

A finalidade do jogo teatral na educação escolar é o crescimento pessoal e o desenvolvimento cultural dos jogadores por meio do domínio, da comunicação e do 
uso interativo da linguagem teatral, numa perspectiva improvisacional ou lúdica. (JAPIASSU, 2001, p. 26)

Propus um jogo simples, adaptado a partir das propostas de Spolin (2001): com os alunos sentados em roda, coloquei ao centro uma bola de papel amassado e estabeleci as regras: cada um deles deveria ir ao centro, pegar o papel e transformá-lo em um outro objeto, diferente daquela bola de papel. Um a um, os alunos começaram a ir. Os mais espontâneos se predispuseram a ir primeiro. Os que apresentavam mais timidez, incluindo as alunas Amanda, Carol e Beatriz, precisaram ser estimulados, provocados a irem. Beatriz, "transformou" a bola de papel em uma escova de cabelo. Carol, sua irmã, em um celular. Amanda, imitou Carol e também simulou um celular com a bola de papel. Não quis censurá-la pela imitação. Nesse momento a participação era mais importante para mim do que a originalidade.

Os jogos estavam funcionando, mas ainda de modo tímido. Afinal, eu era um estranho propondo que eles fizessem coisas "estranhas". Percebi que conforme eles jogavam, iam ficando eufóricos e conversavam muito entre si, muitas vezes sendo necessário que eu falasse cada vez mais alto e chamasse a atenção deles. Procurei, então, narrar minhas próprias dificuldades como ator para criar um vínculo com eles, histórias que, ao mesmo tempo que demonstravam minha vulnerabilidade, mostravam minha tranquilidade em compartilhá-las.

Neste dia, a sala estava bastante indisciplinada. Contei que uma vez me apresentei como ator em um evento e a plateia não prestava atenção em mim; que essa sensação era horrível e que eu não gostaria que eles passassem por isso quando fossem se apresentar para a escola. Eu confidenciei aos alunos que, do mesmo modo, era muito ruim para mim, tentar dar aula e eles não prestarem atenção. Eu me sentia invisível e perguntei a eles se já haviam se sentido invisível alguma vez. As respostas dos alunosforammuito interessantes. Seguem algumas delas:

Eu me senti invisível quando a minha amiga aqui ganhou um celular e ela parou de conversar comigo, só ficava no celular (Ana).

Eu me senti invisível quando minhas amigas fizeram novas amigas e deixaram de falar comigo (Monique).

Eu me sinto invisível quando minha mãe acha que só ela tem problemas (Mayara). 
Compartilhar experiências com os alunos por meio de narrativas, os famosos "causos", mostrou-se muito eficaz para provocar interação e reflexão. É impressionante o quanto eles param para prestar atenção enquanto narramos nossas vivências. E é mais interessante ainda o modo como eles mesmos vão compartilhando suas memórias a partir das nossas. A esse respeito, Biange Cabral (2006) ressalta:

\begin{abstract}
A razão para a inserção de memórias em processos e produtos teatrais se relaciona com a dimensão do pessoal, tal como aumento de auto-estima, interação com sujeitos afins, construção de identidade; e com a dimensão social, como responsabilidade e respeito para com o espaço urbano, engajamento com questões de preservação, atividades sociais e culturais. (p. 13)
\end{abstract}

Percebe-se então que cada aluno é um universo complexo a ser investigado. Ali, não se tratava mais de Amanda, Carol e Beatriz apenas. Todos tinham uma história de vida para compartilhar, muitas delas envolvendo algum tipo de vulnerabilidade emocional. São essas expressões que caracterizam o ensino de Artes com destaque para o Teatro, como chave de acesso à sensibilidade dos alunos.

Destaco outro jogo teatral realizado a partir do fichário de Viola Spolin (2001), chamado "Jogo do Espelho". Neste jogo, a sala é dividida em duplas, aluno A e aluno Bem pé, dispostos um em frente ao outro, devem realizar movimentos sincronizados como se estivessem em frente a um espelho, ou melhor, como se um fosse o espelho do outro. Todos da turma realizam o jogo ao mesmo tempo, sendo que o aluno $A$ começa conduzindo os movimentos do aluno $B$, buscando alternar os planos (alto, baixo, médio). Após um certo período, inverte-se e o aluno $B$ passa a ser o condutor dos movimentos.

Ficou muito nítida a dificuldade em relação a coordenação motora de Amanda, Carol e Beatriz, muito embora Beatriz fosse a que conseguia acompanhar melhor entre as três. Carol fez dupla com Amanda e Beatriz com outro colega da sala. Precisei insistir com Carol e Amanda para que elas não abandonassem o jogo. Procurei proferir palavras de estímulo, dizendo que elas eram capazes, só precisavam se concentrar nos movimentos e ter paciência. Amanda repetia o tempo todo "eu não consigo, professor" e eu tornava a enfatizar "consegue sim". Ao final do jogo, Amanda e Carol já tinham melhorado em relação aos movimentos do jogo, muito embora suas relutâncias ainda fossem evidentes. Eu as estimulei dizendo "estão vendo, como vocês conseguem? Precisam acreditar mais em vocês". O sorriso das duas 
denunciava a alegria no êxito ao conseguir jogar. Ao final da aula, Amanda me procurou e me disse: "professor, eu não acredito em mim". Eu fui surpreendido por essa fala e questionei o porquê dela estar dizendo isso. Ela não soube me explicar, apenas disse "eu não sei, eu só sei que eu não acredito que eu consiga fazer as coisas".

Esse episódio reforça a baixa autoestima que acomete os alunos com Necessidades educacionais especiais e ilustra como o Teatro, por meio do jogo cênico consegue evidenciar e ao mesmo tempo trabalhar essa questão. Ao realizar um jogo teatral, por mais simples que pareça, os alunos com dificuldades de aprendizagem se mostram mais confiantes, o que indica que, em longo prazo isso possa trazer benefícios em sua relação com o ensino-aprendizagem.

A cada desafio vencido, eu me sentia mais confiante no magistério. Contudo, eu continuava sentindo muita resistência em trabalhar com alunos com necessidades educacionais especiais, afinal, eu não me achava preparado. Aliás, não me recordo do assunto ser abordado durante o curso de Licenciatura em Teatro. A minha frustração é que eu senti que poderia ter ido melhor preparado para a sala de aula e conseguido adaptar melhor meus jogos para incluir essas alunas. Fiz o que pude, mas sinto que poderia ter feito mais. Destaco um exercício cênico que sempre funcionava muito em outras experiências, porém, desta vez, ao trabalhar um jogo que pressupunha oralidade em uma sala com uma aluna com disfunção na fala, protagonizei um momento bastante embaraçoso, que registrei em meu diário de bordo do estágio.

O jogo dramático criado por mim a partir de oficinas teatrais com meu grupo de teatro se chama "janela indiscreta". Nele, os alunos, em dupla, se colocam a certa distância um do outro e, frente a frente, devem representar um diálogo de improviso, imaginando que estão acordando pela manhã, abrindo a janela e se deparando com a janela do vizinho indesejado. Essa brincadeira é interessante por trabalhar a criatividade e a improvisação dos alunos, que tendem a deixar a cena cômica na maioria dos casos. Minha preocupação era como adaptá-lo para toda a turma, considerando que Beatriz não podia falar. Reforcei, então, a todos que não precisavam se utilizar da linguagem oral. Podiam apenas trabalhar as expressões faciais, corporais e a linguagem não verbal. Quando chegou a vez de Beatriz realizar o jogo, tudo ia bem até que a colega de Beatriz disse no improviso do jogo dramático: "você não vai falar nada?". Neste instante, a turma toda começou a rir de modo frenético. 
Beatriz, aparentemente constrangida, se fechou para o jogo e eu acabei por encerrar a dinâmica.

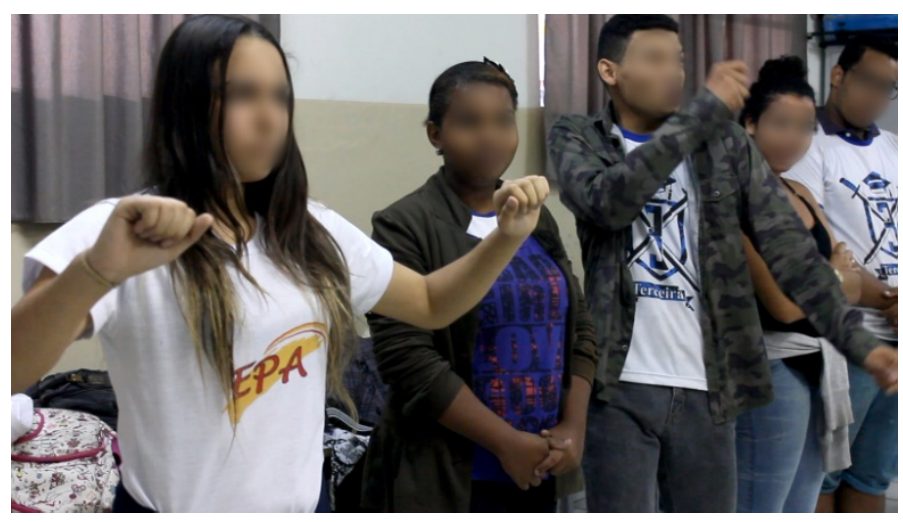

Imagem 2 - Jogo "Janela indiscreta".

A comunicação é de fundamental importância para a educação, no entanto nossas escolas são predominantemente orais e priorizam a verbal. "Mas a capacidade de falar não é a única maneira que temos para nos comunicar" (ATACK, 1995, p. 5). Percebi que o exercício acabava por supervalorizar a oralidade e, por isso, talvez não fosse o mais adequado naquele contexto. Uma ideia paradoxal ainda reside em mim sobre esse episódio: seria melhor não realizar o jogo "janela indiscreta" ou adaptá-lo melhor, levando em consideração a aluna com disfunção na fala? E se uma das regras do jogo fosse a linguagem não-verbal? Mas, então, eu nunca poderia trabalhar a oralidade com essa turma? Como professor, deve-se planejar a aula levando em conta preceitos inclusivos, mas é impossível prever que experiências desagradáveis ocorram. Do mesmo modo que não se pode "blindar" os alunos com necessidades educacionais especiais, evitando assim que passem por suas próprias experiências.

Em tempo, nota-se em meu diário de bordo traços de preconceito de linguagem proveniente da minha falta de informação à época. "Aluna com deficiência na fala" não seria o termo mais correto, mas sim "disfunção na fala", já que a aluna não era uma pessoa com deficiência. Outra questão foi referir à aluna como sendo "aluna especial", que pressupõe uma aluna da Educação Especial, o que também não era o caso. Sassaki (2011) nos alerta sobre a importância de se atentar às terminologias utilizadas ao se falar de deficiência para que não reforcemos preconceitos por meio da utilização de nomenclaturas, termos e expressões que 
estão em desuso. Não se trata apenas de procurar a terminologia mais precisa, mas para que "desencorajemos práticas discriminatórias e construamos uma verdadeira sociedade inclusiva" (p. 1).

Já quase no final do meu período de estágio na escola, decidi trabalhar com o drama em sala de aula. A partir da leitura dos alunos em voz alta do conto "A Primeira Só" de Marina Colasanti, propus que a sala se dividisse em grupos aleatórios — para que houvesse rotatividade nos grupos - e criassem um esquete que falasse sobre amizade, tema do conto.

Como os alunos tinham autonomia para criar a dramaturgia e, consequentemente, distribuir papéis, notei que os alunos mais desenvoltos ocupavam os papéis principais e concentravam as falas. Os que demonstravam mais acanhamento apenas figuravam. Amanda, Carol e Beatriz, por exemplo, interpretaram na dramatização dos seus grupos pessoas que sentavam e assistiam a um show musical, protagonizado por seus colegas.

Percebi que a dificuldade de incluir essas alunas que fogem dos padrões sociais de normatização se estendiam a seus colegas, que acabam por excluí-las das atividades mais interessantes ou subestimar sua capacidade criativa. Na avaliação, algumas alunas se revoltaram contra os colegas e reclamaram da falta de autonomia que enfrentaram com os colegas de grupo, que centralizavam todas as tomadas de decisões. Porém, Amanda, Carol e Beatriz nem mesmo reclamavam, não externavam suas dificuldades. Questioneios alunos acerca das atitudes centralizadoras e eles confessaram que fizeram isso porque as colegas não propunham nenhuma ideia.

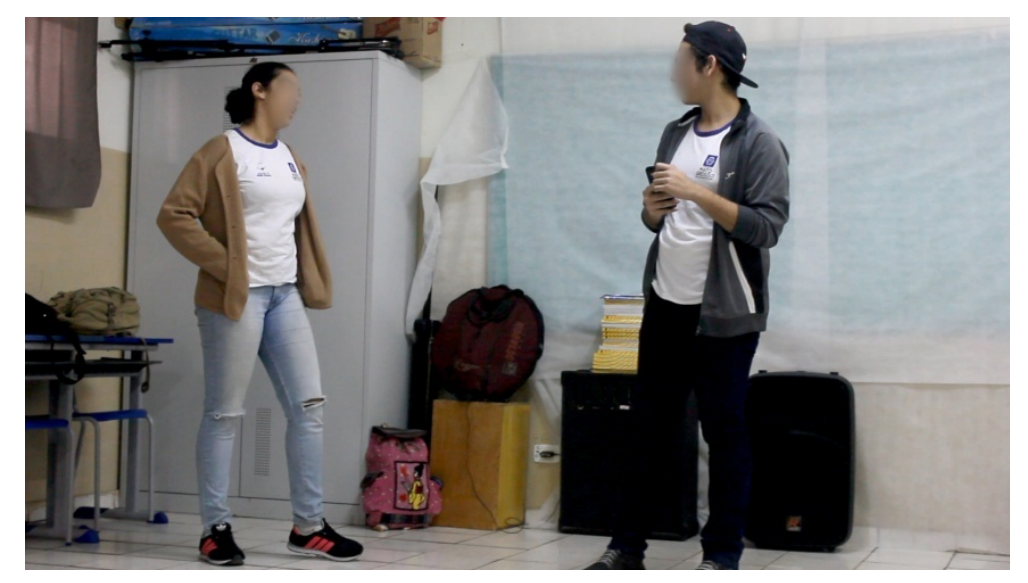

Imagem 3 - Drama em sala de aula. 
Nota-se que ao trabalhar o drama em sala de aula, consegue-se justamente colocar os educandos em situações análogas ou mesmo avessas a sua realidade, proporcionando empatia, expurgo e até mesmo a capacidade de pensar para além da ficção. Ao entrarem em fricção, os alunos são estimulados a externar questões que muitas vezes se sustentam de forma velada. De todo modo, propor construções coletivas de esquetes para fomentar as criações colaborativas e as interações entre os alunos, além, claro, das tomadas de decisões em equipe, é uma decisão assertiva.

O Drama, uma forma essencial de comportamento em todas as culturas, permite explorar questões e problemas centrais à condição humana, e oferece ao indivíduo a oportunidade de definir e clarificar sua própria cultura. É uma atividade criativa em grupo, na qual os participantes se comportam como se estivessem em outra situação ou lugar, sendo eles próprios ou outras pessoas. (CABRAL, 2006, p. 11)

Em minha prática como professor estagiário, percebi que os alunos demonstravam-se empolgados e estimulados em suas criações dramáticas, no entanto, é necessário antes criar um ambiente propício e inclusivo para essas criações. Isso significa dizer que não basta chegar cheio de ideias de jogos dramáticos na cabeça e querer que os alunos realizem. Isso não funciona. Primeiro, é preciso adequá-los dentro de uma proposta de inclusão; conhecer os alunos, contextualizar; fazer os alunos entenderem o propósito de cada atividade. Uma boa conversa é sempre um excelente ponto de partida. Ouvir o que eles têm a dizer e se apresentar apropriadamente são imprescindíveis. Perguntas tais quais exemplifiquei anteriormente, como “vocês já se sentiram invisíveis?”, seguidas do compartilhamento de memórias pessoais, em que confidenciei a eles um momento da minha vida em que me senti invisível, criou cumplicidade.

Jogos teatrais mais sensoriais e com linguagem não-verbal, como o jogo do espelho, se mostraram mais inclusivos nesse contexto de alunos com necessidades educacionais especiais. Entretanto, jogos dramáticos e dramatizações coletivas permitiram um aprofundamento nas dificuldades dos alunos, inclusive as dificuldades de relacionamento da turma.

Reconhecer as dificuldades de aprendizagem dos alunos e adequar o plano de aula de modo a atender toda a turma é uma atividade cotidiana do professor de Teatro. O papel da escola em inserir o assunto da inclusão é imprescindível e o acompanhamento da família é 
crucial. É a família que deve avisar se o filho possui alguma dificuldade de aprendizagem e Necessidades educacionais especiais. Caso esse diagnóstico não venha da família, não cabe ao professor essa função, uma vez que não é preparado pedagogicamente para isso e corre grande risco de recorrer ao preconceito, ao estereótipo. Ao professor cabe observar e informar a equipe pedagógica responsável e cobrar a participação dos pais, uma vez que a presença e o engajamento da família são cruciais para o sucesso escolar do aluno, conforme descreve Smith (2001):

\begin{abstract}
Está comprovado que os estudantes mais propensos a ter sucesso são aqueles que têm pais informados e incentivadores ao seu lado. Esse fator supera a qualidade do programa escolar ou a gravidade da própria deficiência em importância. Muitos estudos têm demonstrado que "cuidados parentais de qualidade" permitem às crianças crescerem e tornarem-se cidadãos felizes e independentes, mesmo quando a saúde ao nascer e as oportunidades educacionais são notavelmente fracas. (p. 17)
\end{abstract}

Sem o interesse efetivo do professor de Teatro, sem o suporte pedagógico da escola e o aporte da família, é bem provável que as dificuldades de aprendizagem de Amanda, Carol e Beatriz continuem representando o fracasso escolar. Para evitar esse fracasso, que pode culminar no abandono da escola, é de suma importância que essas alunas encontrem em seu caminho acadêmico professores preparados para ministrar aulas que as incluam sem empobrecer currículos para isso. Quanto a mim, um professor que inicia sua jornada, sinto que aprendi muito mais com essas alunas do que pude retribuir e essa constatação para mim é é paradoxal, pois representa uma alegria e uma tristeza, ou seja, "festa e funeral". 


\section{CONSIDERAÇÕES FINAIS}

A licenciatura ainda apresenta falhas ao introduzir professoresna Educação Inclusiva, sobretudo no que diz respeito aos alunos com necessidades educacionais especiaisdo ensino regular. Além disso, a formação continuada, de um modo geral, tem abordado de modo muito tímido o tema. O resultado são professores inseguros, que não se sentem preparados para ensinar alunos com dificuldades de aprendizagem, contribuindo para a propagação das distinções de currículos em sala de aula e a manutenção de estereótipos.

Grande parte das escolas, por sua vez, carece de projetos políticos pedagógicos que garantam a inclusão desses alunos. A falta de diagnósticos que justifiquem a intervenção de professores especializados para trabalharem com os alunos com necessidades educacionais especiais são nítidas, uma vez que essas escolas não dispõem de laudos periciais, nem mesmo conseguem estreitar o diálogo com seus familiares para buscarem juntos alternativas.

A inclusão educacional não pode servir de pretexto para que alunos com dificuldades acentuadas de aprendizagem sejam inseridosem sala de aula sem que haja o preparo e a mobilização da comunidade escolar para garantir umaeducação de qualidade a esses discentes, conferindo-lhes condições plenas de exercerem sua cidadania.

A minha experiência como professor estagiário na rede pública de ensino mostrou que o ensino do Teatro pode ser uma poderosa ferramenta tanto para perceber as dificuldades de aprendizagem quanto para superá-las. Por meio das aulas, os alunos exercitaram sua sensibilidade, seu protagonismo e o respeito à diversidade ao se colocarem em situações nas quais precisavam conviver com as diferenças pessoais, culturais e sociais dos colegas.

A fricção causada pelos exercícios de dramatização realizados em sala de aula com alunos com Necessidades educacionais especiais foi capaz de externar preconceitos velados pelos colegas, o quepossibilitou o diálogo sobre o respeito às diferenças. Diferenças essas que poderiam permanecer incubadas por métodos tradicionais de ensino. Além disso, o drama como exercício cênico, permitiu aos educandos a experiência estética e o pensamento crítico, 
habilidades primordiais na proposta de se dissolver dificuldades de interação social em comparação com realidades exteriores.

Os jogos teatrais e dramáticos permitiram a participação da turma toda e, ao suscitar o contato com o lúdico e a auto-expressão, fez com que se evidenciassem as dificuldades de aprendizagem dos alunos, o que em métodos tradicionais, como aulas expositivas, não foram possíveis de perceber. Essa percepção é importante, não para que se proclamem rótulos ou diagnósticos médicos, mas para que o professor exercite sua sensibilidade e crie métodos de ensino que possam atender a todos. Desse modo, alunos com Necessidades educacionais especiais podem ter suas potencialidades trabalhadas, evitando seu fracasso.

Ir para a sala de aula sabendo da existência de alunos com Necessidades educacionais especiaisé de suma importância ao professor. Os cursos de licenciatura têm por obrigação introduzir essa matéria aos acadêmicos. Por sua vez, isso não anula o dever dos professores de procurarem se aprofundar no assunto.

Pude perceber com a pesquisa, que para realizar uma aula que contemple a turma toda de fato, o professor, em particular o de Teatro, precisa estar disposto a adaptar sua metodologia para garantir a participação de todos os alunos. Concluo que é fundamental conhecer o contexto da comunidade escolar, as dificuldades de aprendizagem e Necessidades educacionais especiais do aluno, para que ele seja considerado a partir de suas potencialidades e não apenas de suas dificuldades. Só assim o ensino do Teatro poderá ser realizado com primazia, potencializando inclusive outras áreas de conhecimento de modo multidisciplinar.

A partir dessa pesquisa, entrei em contato com ideias que não conhecia, entre elas o próprio conceito de alunos com Necessidades educacionais especiais. Para incluir, é preciso conhecer. Saber que nenhum ser humano é igual e que essa diversidade é o que enriquece o magistério. E que as dificuldades de aprendizagem se apresentam de forma sutil, que não existe um padrão de alunos com dificuldades, tampouco de aluno ideal.

Percebi também que o ensino do Teatro, pode atuar na linha de frente com os alunos com dificuldades de aprendizagem, pois, ao propor simples superações diárias, trabalha a autoestima e pode reverberar em questões muito mais complexas como o sucesso pessoal e profissional. 


\section{REFERÊNCIAS BIBLIOGRÁFICAS}

AFFONSO, Dolores. Opinião: Educação especial ou inclusiva? Disponível em: $<$ http://www.todospelaeducacao.org.br/educacao-na-midia/indice/30994/opiniao-educacaoespecial-ou-inclusiva/> Acessado em 20 de janeiro de 2018.

ATACK, Sally M. Atividades artísticas para deficientes / Sally M. Atack : tradução Thaís Helena F. Santos -- Campinas, SP : Papirus, 1995 -- (Coleção Educação Especial)

BRASIL. Constituição da República Federativa do Brasil de 1988. Disponível em: $<$ http://www.planalto.gov.br/ccivil_03/constituicao/constituicaocompilado.htm> Acessado em 06 de setembro de 2017.

BRASIL. Lei n. 7.853, de 24 de outubro de 1989. Dispõe sobre o apoio às pessoas portadoras de deficiência, sua integração social, sobre a Coordenadoria Nacional para Integração da Pessoa Portadora de Deficiência - Corde, institui a tutela jurisdicional de interesses coletivos ou difusos dessas pessoas, disciplina a atuação do Ministério Público, define crimes, e dá outras providências. Disponível em: <http://www.planalto.gov.br/ccivil_03/leis/L7853.htm> Acesso em: 06 de setembro de 2017.

BRASIL. Lei $\mathbf{n}^{0}$. 9.394, de 20 de dezembro de 1996. Estabelece as diretrizes e bases da educação nacional. Disponível em: < http://www.planalto.gov.br/ccivil_03/leis/19394.htm>Acessado em 10 de setembro de 2017.

BRASIL. Lei $\mathbf{n}^{\mathbf{0}}$. 13.146, de 6 de julho de 2015. Institui a Lei Brasileira de Inclusão da Pessoa com Deficiência (Estatuto da Pessoa com Deficiência). Disponível em: $<$ http://www.planalto.gov.br/ccivil_03/_ato2015-2018/2015/lei/l13146.htm>Acessado em 18 de janeiro de 2018

BRASIL. MEC, Secretaria de Educação Especial. Projeto Escola Viva - Garantindo o acesso e permanência de todos os alunos na escola - Alunos com necessidades educacionais especiais. Brasília. 2002, Série 2. Disponível em < http://www.dominiopublico.gov.br/download/texto/me000453.pdf $>$ Acessado em 21 de fevereiro de 2018.

BRASIL. MEC, Secretaria de Educação Especial. Saberes e práticas da inclusão : recomendações para a construção de escolas inclusivas. [2. ed.] / coordenação geral SEESP/MEC. - Brasília : 2006.

BRASIL. Secretaria de Educação Fundamental.Parâmetros curriculares nacionais : arte / Secretaria de Educação Fundamental. - Brasília : MEC/SEF, 1997. 130p. Disponível em

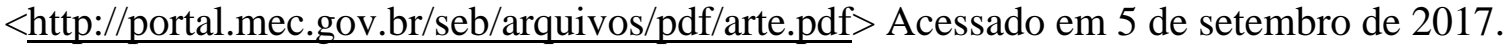


CABRAL, Beatriz. Drama como método de ensino. São Paulo: Editora Hucitec: Edições Mandacaru, 2006.

CABRAL, Biange. O Professor-artista: Perspectivas Teóricas e Deslocamentos Históricos. Urdimento - Revista de Estudos em Artes Cênicas / Universidade do Estado de Santa Catarina. Programa de Pós-Graduação em Teatro. - Vol 1, n.10 (Dez 2008) Florianópolis: UDESC/CEART. Disponível em $<$ http://www.revistas.udesc.br/index.php/urdimento/article/viewFile/5431/3629> Acessado em: 04 de fevereiro de 2018

DOS SANTOS, Alex Reis; TELES, Margarida Maria. Declaração de Salamanca e Educação Inclusiva. $3^{\circ}$ Simpósio Educação e Comunicação :Infoinclusão: possibilidades de ensinar e aprender. Edição Internacional. Anais, 2012.

FERREIRA, Aurora. Arte, Escola e Inclusão : atividades artísticas para trabalhar com diferentes grupos. 2. ed. Petrópolis, RJ : Vozes, 2011.

FREIRE, Sofia. UM OLHAR SOBRE A INCLUSÃO. Instituto Superior D. Afonso III. Revista da Educação, Vol. XVI, nº 1, 2008.

GAMA, Joaquim. Produto ou Processo: em qual deles estará a primazia? São Paulo: Sala Preta - Revista do Departamento de Artes Cênicas - ECA/USP, 2002. Disponível em

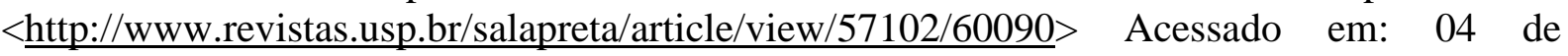
fevereiro de 2018.

GLAT, Rosana; MASCARENHAS FERNANDES, Edicléa. Da Educação Segregada à Educação Inclusiva: uma Breve Reflexão sobre os Paradigmas Educacionais no Contexto da Educação Especial Brasileira. Faculdade de Educação / Universidade do Estado do Rio de Janeiro. Artigo publicado na revista Inclusão. 2005. Disponível em: $<$ http://forumeja.org.br/sites/forumeja.org.br/files/Da\%20Educa\%C3\%A7\%C3\%A3o\%20Seg regada\%20\%C3\%A0\%20Educa\%C3\%A7\%C3\%A30\%20Inclusiva.pdf $>$. Acesso em 18 de setembro de 2017.

GOVERNO de Mato Grosso. CONCURSO PÚBLICO EDITAL No . 01/2017 - 03 DE JULHO DE 2017.2 Disónível em $<$ http://www.ibfc.org.br/concurso/concurso_selecionado/310 $>$ Acessado em 3 de fevereiro de 2018.

HARTMANN, Luciana; FERREIRA, Taís. Módulo 16 : História da Arte-Educação 2. Brasília: LGE Editora, 2009. 74. Disponível em $<$ https://pt.slideshare.net/plateroeeu/historiaarte-ed2teatro2 >. Acessado em: 04 de fevereiro de 2018

HUIZINGA , J. Homo ludens. São Paulo, Ed. Perspectiva, 1999.

JAPIASSU, Ricardo. A linguagem Teatral na Escola: pesquisa, docência e prática pedagógica. Campinas: Papirus Editora, 2007. 
MRECH, Leny Magalhães. O que é Educação Inclusiva? Faculdade de Educação da Universidade de São Paulo. Disponível em: $<$ http://www.luzimarteixeira.com.br/wpcontent/uploads/2010/10/1-o-que-e-educacao-inclusiva.pdf $>$. Acessado em 5 de setembro de 2017.

PAVIS, Patrice, 1947.Dicionário de teatro. Patrice Pavis :tradução para a língua portuguesa sob a direção de J. Guinsburg e Maria Lúcia Pereira. - São Paulo : Perspectiva, 2017.

PUPO, Maria Lúcia de Souza Barros. O lúdico e a construção do sentido. São Paulo: Sala Preta - Revista do Departamento de Artes Cênicas - ECA/USP, 2001. Disponível em

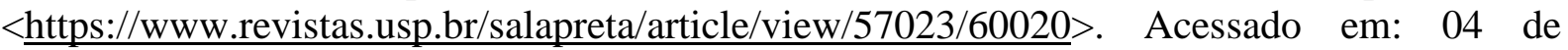
fevereiro de 2018

RODRIGUES, D. (2000). O Paradigma da educação inclusiva: reflexões sobre uma agenda possível. Inclusão, 1, 7-13.

SANCHES, Isabel. Compreender, Agir, Mudar, Incluir. Da investigação-acção à educação inclusiva. Revista Lusófona de Educação, 2005, 5, 127-142. Disponível em:

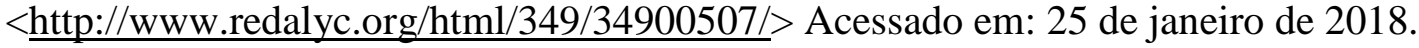

SASSAKI, Romeu Kazumi. Terminologia sobre deficiência na era da inclusão. 2011. Disponível em $\quad<$ http://www.ocuidador.com.br/imgs/utilidades/terminologia50aa23697289a.pdf $>$ Acessado em 4 de fevereiro de 2018.

SMITH, Corinne. Dificuldades de aprendizagem de A aZ : um guia completo para pais e educadores / Corinne Smith, Lisa Strick ; tradução Dayse Batista. - Dados eletrônicos. Porto Alegre : Artmed, 2007

SPOLIN, Viola. Jogos teatrais: o fichário de Viola Spolin. São Paulo: Perspectiva, 2001.

UNESCO. Declaração de Salamanca sobre Princípios, Política e Práticas na Área das Necessidades Educativas $\quad$ Especiais. 1998. Disponível em

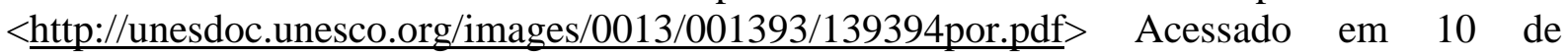
setembro de 2017. 


\section{ANEXOS}

I - Diários de bordo mencionados durante o trabalho.

II - Alguns modelos de planos de aula realizados surante o estágio 


\section{ANEXO 01}

I - Diários de bordo mencionados durante o trabalho.

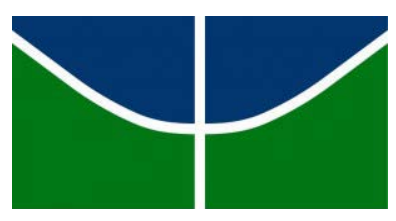

Universidade de Brasília

Instituto de Artes

\section{Departamento de Artes Cênicas}

\section{Estágio Supervisionado 3}

\section{Relatório de Estágio - 01}

\section{Aula para eletiva de teatro da Escola Estadual Antônio Epaminondas}

Em minha primeira aula de estágio supervisionado do curso de Licenciatura em Teatro, tive o prazer de lecionar em uma escola pública de ensino em tempo integral.

A Escola Estadual Antônio Epaminondas é umas das quinze escolas que foram contempladas com o nome projeto pedagógico chamado pelo Governo de Mato Grosso como "Escola Plena". Nela, os alunos estudam em tempo integral, passando mais tempo dentro da escola do que em suas próprias casas, com suas famílias. É um projeto interessante e pioneiro em Cuiabá, cidade sede da escola.

Iniciei a aula com um exercício simples de apresentação dos nomes. Com todos os alunos em pé, dispostos em círculo, instruí-los a, um de cada vez, dar um passo a frente e dizer seu nome e, com a inicial de seu nome, realizar um gesto de algo que gostasse de fazer. Dei o exemplo: “meu nome é Eduardo e eu gosto de escrever”. Na sequência, todos foram se apresentando. 
Recomendei que todos prestassem bastante atenção em como o colega estava se apresentando, pois o exercício seguinte exigiria isso. Em seguida, pedi para que se apresentassem como se fossem o colega a sua esquerda, tentando reproduzir ao máximo o modo como o colega havia se apresentado na primeira rodada. Fiz uma observação: “é importante que vocês respeitem o colega e não tente zombar da forma como ele se apresentou. A ideia não é uma caricatura do colega, mas ser fiel e um bom observador do modo como o outro se expressa”. Fiz essa ênfase, pois, ao realizar o mesmo exercício no Estágio 2, para uma turma da oitavo ano, a “imitação” muitas vezes esbarrou na zombaria como colega, que não tinha nenhum objetivo senão a chacota com o outro. Dessa vez, já antevi esse comportamento, orientando-os do real objetivo do exercício. Todos compreenderam.

Esse simples jogo de apresentação dos nomes seguido pela mimese foi muito proveitoso

O próximo passo foi apresentar um slide sobre o Teatro Grego, o berço do teatro ocidental, os gêneros Tragédia e Comédia e os aspectos culturais e políticos da Grécia, que são indissociáveis do Teatro Grego. Tive receio de não cansá-los e parei procurava sempre pela interação deles, com perguntas muitas vezes retóricas, mas que ajudavam a pensar, como por exemplo: “alguém se arrisca a dizer o que é comédia?”. Eu perguntei também se eles estavam achando o conteúdo pesado, que, se sim, podíamos continuar na aula seguinte e irmos diretor para a segunda parte da aula, os exercícios práticos. Eles me autorizaram a continuar e se mostraram bastante interessados, em especial quando eu contei um resumo de "Édipo Rei” para exemplificar o gênero trágico. Os alunos ficaram abismados com o fato da predestinação de Édipo que acabou matando o pai e desposando a própria mãe conforme o oráculo havia previsto.

Quando eu disse que no Teatro Grego as mulheres eram proibidas de interpretar, pois não eram consideradas cidadãs, pedi a opinião das meninas da sala, sobre o que elas achavam disso. Uma logo bradou: “Acho isso ridículo. Machismo”. Eu comentei que Teatro também é um ato político e que a presença das mulheres representava uma luta de séculos, uma ocupação de espaço por direitos iguais.

O professor da disciplina de artes esteve presente o tempo todo. Achei interessante a postura dele que foi de assistir a minha aula de modo bem receptivo, como se estivesse também ele aproveitando o meu conteúdo. Ele também me ajudou nos intervalos da aula a colocar os 
alunos de volta na sala, já que, eles "saem e esquecem de voltar”, como disse o próprio professor.

Depois do intervalo, falei sobre as máscaras gregas (personas) e sua função no Teatro Grego. Mostrei algumas imagens e falei da sua funcionalidade naquele tipo de teatro. Falei também que as máscaras imitavam as expressões humanas de "alegria”, "tristeza”, "raiva” e daí por diante. Entreguei a eles um material didático com seis formas básicas de expressões e pedi para que tentassem reproduzi-las. Individualmente, poucos se atreveram. Os alunos são muito tímidos, travados eu diria. Então, propus um jogo em que todos fizessem as expressões ao mesmo tempo. Como o jogo lúdico do “morto-vivo, vivo-morto", coloquei todos juntos à frente da sala e fui dando as instruções para que eles mudassem as expressões faciais conforme meu comando de voz. Desse modo, quando eu dissesse "alegre”, todos deveriam fazer essa expressão, “morto”, a mesma coisa e daí por diante. Notei que em conjunto, no jogo teatral, eles respondem muito melhor do que individualmente. Pretendo apostar mais nisso nas próximas aulas.

Houve até um momento interessante, quando eu tentei que eles fizessem as expressões faciais individualmente e fui, um a um, pedindo que fizesse. Uma aluna me disse "professor, não me sinto preparada”. Eu disse "tudo bem”. Achei madura a postura dela em me dizer que não se sentia "no jogo". Percebi que, muitas vezes, aquele aluno bagunceiro ou aquele aluno “emburrado” que não quer participar “não se sente preparado”, mas não sabe como dizer isso ao professor. O interessante é que essa mesma aluna se saiu muito bem no mesmo exercício em coletivo com os colegas.

Sentamos todos no chão, em círculo, e fizemos uma roda de discussão. Eu disse que queria ouvi-los, já que eu já havia falado demais. Queria saber deles o "porquê” de terem escolhido o Teatro como disciplina eletiva e quais eram suas expectativas em relação as aulas. A grande maioria admitiram que procuraram o teatro para tentar se livrar da timidez e a expectativa era que, ao final do curso, pudessem estar “mais soltos”. Eu, particularmente, acho um tanto cruel o quanto nossos jovens são reprimidos e tímidos. Se o Teatro puder contribuir com isso, só com isso, já está bom. Embora eu saiba que o Teatro é capaz de muito mais.

Ao final, restavam alguns minutos e, como uma moeda de troca, mostrei a eles alguns vídeos meus do meu canal de humor na internet. Disse a eles que os vídeos eram todos produzidos por gente aqui mesmo da cidade e que é importante eles saberem que teatro não é só uma 
coisa que acontece no Rio de Janeiro e em São Paulo. Eles riram bastante dos vídeos e saíram alegres das aulas.

A minha preocupação agora é de não deixar “cair o nível” das aulas. Que eu consiga manter a aula sempre interessante e que eu consiga, de algum modo, contribuir para o aprendizado deles. 


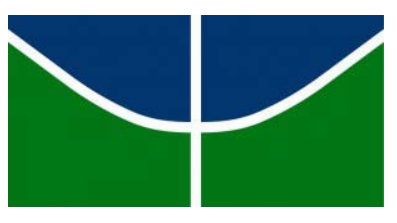

Universidade de Brasília

Instituto de Artes

Departamento de Artes Cênicas

Estágio Supervisionado 3

Professora autora: Fabiana Marroni Tutor a distância: Ricardo Cruccioli Ribeiro Tutora Presencial: Erenil Oliveira Magalhães

Aluno: Eduardo de Freitas Butakka

Relatório de Estágio - 04

Barra do Bugres/MT

2017 


\section{O reflexo no espelho}

Após uma semana sem aula, por conta de problemas de saúde, retomei a aula na Escola Estadual Antônio Epaminondas.

Assim que cheguei, alguns alunos disseram que sentiram minha falta e isso, ainda que tenha sido apenas por educação, me deixou feliz, pois demonstrou sensibilidade da parte deles.

Como de costume, a aula custou a iniciar porque os alunos ficam sempre muito agitados durante os intervalos entre as aulas, em especial após o intervalo do lanche. Demoram para retornar pras sala e quando voltam estão agitados e dispersos.

Dois alunos estavam mais agitados que os demais, então, voltei minha atenção para eles e propus de cara uma dinâmica. Pedi para que os dois, mais uma menina fossem até a frente da sala que iríamos começar um “espetáculo” e o restante da sala seria a plateia. Eu disse "eu darei um comando e vocês terão de executar”. Pedi para que levantassem a perna direita. Os três o fizeram. Pedi para levantarem a perna esquerda. Cumpriram com a proposta novamente. Após isso, pedi para que levantassem as duas pernas ao mesmo tempo, sem se sentarem, deitarem, pularem ou ficarem de ponta cabeça. A primeira reação foi “Ah, professor, impossível fazer isso". Eu insisti “vocês precisam se concentrar e raciocinar para cumprir o desafio”. Houve momentos de dispersão, então a sala começou a dar palpites com o intuito de ajudar os três colegas. Uma das alunas da plateia disse "apoia um no outro". Então, os três, decidiram tentar o seguinte: a aluna do meio dependurou-se no outro dos dois colegas do lado e ergueu os pés do chão. Pronto. Dever cumprido. Essa era a minha deixa e eu disse: "estão vendo? No teatro, a gente nunca está sozinho. É preciso ouvir, é preciso compartilhar e é preciso colaborar para cumprir o objetivo. Vocês cumpriram o objetivo porque se ajudaram. Agora, eu preciso que vocês colaborem e me ajudem a cumprir o meu, que é o de dar aula”. Os alunos ficaram quietos e eu os senti mais próximos de mim nesse momento. Foi como se, ao propor uma dinâmica interessante e, ao mesmo tempo, demonstrar minha vulnerabilidade em precisar a ajuda deles eu criasse um ambiente de empatia na sala de aula.

Eu os lembrei que em breve eles terão que apresentar uma peça na escola, como conclusão das aulas eletivas de teatro e que eles vão precisar, além da dedicação, da colaboração da plateia. Porque é horrível quando o ator está em cena e a plateia não presta atenção. É horrível se sentir invisível. E perguntei: “vocês já se sentiram invisível?”. A resposta de alguns alunos foi bastante interessante. Algumas delas: 
"Eu me senti invisível quando a minha amiga aqui ganhou um celular e ela parou de conversar comigo, só ficava no celular”.

"Eu me senti invisível quando minhas amigas fizeram novas amigas e deixaram de falar comigo".

“Eu me sinto invisível quando minha mãe acha que só ela tem problemas”.

Eu, sempre que posso, procuro estabelecer um diálogo filosófico com os alunos, alguma coisa que parta do dia a dia deles e que os façam pensar, expressar suas emoções. Eu tenho notado que os alunos têm muito problema de autoestima, de autoconfiança. Eu percebo também que após discutirem assuntos mais existenciais, os alunos se sentem mais à vontade para participar da aula, dos exercícios.

Em seguida, pedi para que os alunos lessem, em uma leitura colaborativa, o conto infantojuvenil de Marina Colasanti “A primeira só”. O conto fala de uma jovem princesa que não tinha amigos. O rei, seu pai, cansado de ver a filha triste e sozinha, pediu para construírem um grande espelho e uma bola de ouro para ela brincar. Quando ela acordou, deparou-se com seu reflexo no espelho e acreditou ser outra menina a sua frente, uma amiga. Jogou a bola de ouro para sua amiga e partiu o espelho, descobrindo então não uma, mas várias amigas a cada pedaço de espelho quebrado. A menina, então, passa a quebrar os pedaços de espelho cada vez mais, até reduzi-lo a pó. Sozinha novamente, a menina vê seu reflexo no lago e, acreditando ser sua amiga, mergulha atrás do seu reflexo.

Após a leitura, fiz uma roda de discussão para saber o que haviam entendido do conto. Os níveis de compreensão do texto são diversos na turma. Alguns possuem dificuldades em interpretar texto, em apreender o que é lido, em especial três alunas especiais cujas quais eu não sei qual a natureza da sua deficiência. Eu, então, deixo que os alunos expliquem o que entenderam aos colegas e em seguido complemento.

Dividi os alunos em duplas e propus que fizessem o exercício do Reflexo no Espelho. Assim, um de frente pro outro, deveria imitar os movimentos do outro em sincronia.

Percebi mais uma vez a dificuldade que os alunos têm com exercícios simples. Dificuldade de concentração, principalmente. Começam a rir, não conseguem encarar o colega de frente sem ocasionar um riso patético, sem razão de ser. Aos poucos e com minha supervisão, eles foram recobrando a concentração e o exercício se cumpriu.

Após o intervalo da aula, coloquei-os em roda e realizei o exercício de improviso a partir de uma bola de papel. $\mathrm{O}$ aluno deveria ir ao centro e fingir que aquela bola de papel amassado 
era outro objeto. Com algum estímulo e até mesmo após a iniciativa dos colegas mais proativos, os tímidos e com algumas limitações iniciais foram se soltando e conseguiram realizar o exercício.

O último exercício foi dividi-los em grupos de 4 a 5 pessoas para realizar o primeiro jogo dramático. Eles deveriam, a partir do conto lido e dos exercícios realizados, criar um esquete, uma cena curta e apresentar. Dei para eles um tempo de 15 minutos para se reunirem e criar. No entanto, o tempo não foi suficiente e acabei deixando para que apresentem na próxima aula.

Eu permiti esse adiamento porque, realmente, a aula foi proveitosa e os senti empolgados em sua criação. Estou ansioso para ver o que apresentarão na próxima aula. 


\section{ANEXO 02}

II - Alguns exemplos de planos de aula realizados surante o estágio

I.Plano de Aula: Data: 26/04/2017

II. Dados de Identificação:

Escola: E. E. Epaminondas

Professor (a) estagiário (a): Eduardo de Freitas Butakka

Disciplina: Teatro

Faixa etária: 14 a 18 anos

Período: Matutino

\section{Tema:}

- Tragédia e Comédia: a história do teatro

IV. Objetivos: Introduzir a história do teatro por meio de jogos teatrais e dramáticos

Objetivo geral: Conhecer a origem do teatro Greco-romano, as máscaras da tragédia e da comédia e suas funções no teatro clássico.

\section{Objetivos específicos:}

- Conhecer as máscaras do teatro clássico

- Introduzir a história do teatro grego

- Jogar o jogo das máscaras (alegre, triste, com raiva, assustado, com medo, com nojo)

\section{Conteúdo:}

1 - Apresentação (exercício dos nomes)

2 - Introdução do teatro grego por meio de slides e vídeos 
3 - Introdução as máscaras do teatro clássico grego (personas)

4 - Preparação para os jogos teatrais

5 - Aquecimento de voz (intensidade, altura e timbre)

6 - Aquecimento de corpo

7 - Realização do jogo teatral das máscaras (alegre, triste, com raiva, assustado, com medo, com nojo)

8 - Roda de bate papo

\section{Desenvolvimento do tema:}

Esta aula é pensada como início do meu estágio 3 na E. E. Epaminondas. A pedido da escola, terei de abordar como introdução a disciplina eletiva de teatro a origem do teatro clássico grego.

Elaborei um conteúdo didático interessante, com bastante imagens, vídeos, já que os alunos são pré vestibulandos e o conteúdo didático é importante. E como exercício de fixação e abstração, elaborei um jogo que chamo de "jogo das máscaras" ou "jogo das personas", no qual, baseado no jojo lúdico do "morto ou vivo", os alunos terão de alternar, ao meu comando, as expressões do rosto entre alegre, triste, com raiva, assustado, com medo, com nojo.

\section{Recursos didáticos:}

- Projetor multimídia

- Caixa de som

- Computador

\section{Avaliação:}

Roda de bate-papo para saber suas apreensões sobre a aula e sobre as apresentações dos colegas e até mesmo uma autoavaliação.

XIX. Referência:

BERTHOLD, Margot. História Mundial do Teatro. São Paulo: Perspectiva, 2014 
I.Plano de Aula: Data: 27/04/2017

II. Dados de Identificação:

Escola: E. E. Epaminondas

Professor (a) estagiário (a): Eduardo de Freitas Butakka

Disciplina: Teatro

Faixa etária: 14 a 18 anos

Período: Matutino

III. Tema:

- Iniciando o processo dramatúrgico

IV. Objetivos: Estimular a produção dramatúrgica a partir de jogos dramáticos

Objetivo geral: Experimentar a criação de um texto dramatúrgico colaborativo a partir de exercícios de estímulos e leitura de referências.

\section{Objetivos específicos:}

- Ler contos curtos como referência dramatúrgica

- Pensar nas possibilidades de encenação desse texto

- Criar um microconto colaborativo

- Apresentar o microconto criado pelo colega como monólogo

\section{Conteúdo:}

1 - Alongamento

2 - Aquecimento de voz (intensidade, altura e timbre)

3 - Aquecimento de corpo

4 - Leitura colaborativa de um conto chamdao "Sem Novidades do Front" do livro "Contos de amor rasgados" de Marina Colasanti

5 - Criar uma tábua de palavras: a partir do texto lido, os alunos deverão selecionar aquelas que Ihes chamaram atenção

6 - Anotar as palavras num papel e trocar com o colega, justificando a escolha de cada palavra

7 - A partir das palavras selecionadas, criar um microconto para ser apresentado em forma de monólogo

8 - Trocar o conto criado com outro colega para que cada aluno apresente o texto do outro

\section{Desenvolvimento do tema:}


Esta aula é pensada como introdução a aos jogos dramáticos e a própria dramaturgia colaborativa dos alunos da aula eletiva de Teatro da escola Epaminondas. A ideia é promover o "brainstorm" de ideias entre o grupo para estimulá-los na criação dramatúrgica a partir de jogos dramáticos.

\section{Recursos didáticos:}

Livro de contos "Contos de Amor Rasgados"

\section{Avaliação:}

Roda de bate-papo para saber suas apreensões sobre a aula e sobre as apresentações dos colegas e até mesmo uma autoavaliação.

\section{Referência:}

COLASANTI, Marina. Contos de Amor Rasgados. Rocco, 2010.

CABRAL, Beatriz Ângela Vieira. O Drama Como Método de Ensino. Hucitec, 2012. 